California Western School of Law

CWSL Scholarly Commons

Faculty Scholarship

2012

\title{
The International Labour Organization and International Labor Standards
}

Roger Blanpain

Susan Bisom-Rapp

California Western School of Law, SBisom-Rapp@cwsl.edu

William R. Corbett

Louisiana State University Law Center, bill.corbett@law.Isu.edu

Hilary K. Josephs

Syracuse University College of Law, hkjoseph@syr.edu

Michael J. Zimmer

Follow this and additional works at: https://scholarlycommons.law.cwsl.edu/fs

Part of the Comparative and Foreign Law Commons, and the Labor and Employment Law Commons

\section{Recommended Citation}

Roger Blanpain, Susan Bisom-Rapp, William R. Corbett, Hilary K. Josephs \& Michael J. Zimmer, The International Labour Organization and International Labor Standards, The Global Workplace: International and Comparative Employment Law Cases and Materials (2012).

Available at: https://scholarlycommons.law.cwsl.edu/fs/343

This Book Chapter is brought to you for free and open access by CWSL Scholarly Commons. It has been accepted for inclusion in Faculty Scholarship by an authorized administrator of CWSL Scholarly Commons. For more information, please contact alm@cwsl.edu. 


\section{The INтRenatтома Labour Organization AND INTERNATIONAL LABOR STANDARDS}

\section{A. Introduction}

That inferior labor conditions in one country can supply it with a trade advantage over its competitors is not an idea of recent vintage. Likewise, pleas for universal labor standards on humanitarian and economic grounds were first made in the nineteenth century. Edward E. Potter, The International Labor Organization, in InTERnATIONAL LABOR AND EMPLOYMENT LAws 85-2 (3d ed., William L. Keller \& Timothy J. Darby eds., 2009) (hereinafter Potter, The ILO). Despite some incipient efforts, however, scant progress was made toward establishing global labor standards until 1919. In that year, in the aftermath of World War I, the International Labour Organization (ILO) was established by the Treaty of Versailles as an autonomous body within the ill-fated League of Nations. Bob Hepple, Labour Laws and Global Trade 29-30 (2005). The IlO survived the disintegration of League, becoming in 1946 a specialized, tripartite agency of the United Nations, with member nations sending delegations comprised of representatives from government, organized labor, and employers. As of May 2011, it had 183 member countries.

Animating the formation of the new organization in 1919 were the goals of promoting fair trade and ensuring worker protection from exploitation. The ILO was also founded on the principle that advancing social justice is a key element to establishing lasting peace. To those ends, the ILO's role is to promulgate and promote international standards for implementation by its member nations. Traditionally, the agency principally advanced its goals by adopting conventions and recommendations. Lee Swepston, International Labour Law, in Comparative Labour LaW and Industrial Relations in Industrialized Market Economies 141, 142 (10th ed., Roger Blanpain ed., 2010) (hereinafter Swepston, International Labour Law). Conventions are binding legal instruments on the countries that ratify them, while recommendations provide guidance. $I d$. at 143. More recently, however, the ILO has focused on additional 
66 Chapter 2 The International Labour Organization and International Labor Standards

techniques, including adopting declarations and pursuing its decent work campaign.

Guiding the work of the agency at its inception were nine principles of special importance set forth in Article 427 of the Treaty of Versailles. The list included a statement that labor should not be regarded as a commodity or article of commerce, recognition of employees' freedom of association, endorsement of the 8-hour workday or 48-hour workweek standard, and an admonition that men and women should receive equal pay for work of equal value. Potter, The ILO, at 85-4-85-5.

Despite the lofty language of Article 427, human rights concerns received little attention by the ILO in the period between 1919 and 1939. Breen Creighton, The Future of Labour Law: Is There a Role for International Labour Standards?, in The Future of Labour Law 253, 254 (Catherine Barnard, Simon Deakin \& Gillian S. Morris eds., 2004). With the exception of Convention No. 29, Forced Labour (1930), the conventions adopted were generally more technical and prescriptive in orientation. For example, among the early conventions adopted were the Hours of Work Convention, which mandated adherence to the 8-hour workday/48-hour workweek standard, and conventions restricting night work for women and young persons. Indeed, the ILO in its early years made no distinction between labor standards and human rights, instead viewing all conventions as mechanisms for ensuring worker dignity and social justice. Janice R. Bellace, Achieving Social Justice: The Nexus Between the ILO's Fundamental Rights and Decent Work, 15 EmP. RTs. \& EMP. Pol'y J. 5, 11 (2011).

\section{B. The ILO Declarations}

As World War II drew to a close, human rights concerns came to the fore, beginning with the 1944 Declaration of Philadelphia, which was annexed to the ILO Constitution.

\section{Declaration Concerning the Aims and Purposes of the International Labour Organization (Declaration of Philadelphia)}

ILO Constitution, as amended Oct. 9, 1946, Annex, 62 Stat. 3485, 15 U.N.T.S. 35

I

The Conference reaffirms the fundamental principles on which the Organization is based and, in particular, that -

(a) labour is not a commodity;

(b) freedom of expression and of association are essential to sustained progress; 
(c) poverty anywhere constitutes a danger to prosperity everywhere;

(d) the war against want requires to be carried on with unrelenting vigor within each nation, and by continuous and concerted international effort in which the representatives of workers and employers, enjoying equal status with those of governments, join with them in free discussion and democratic decision with a view to the promotion of the common welfare.

\section{II}

Believing that experience has fully demonstrated the truth of the statement in the Constitution of the International Labour Organization that lasting peace can be established only if it is based on social justice, the Conference affirms that -

(a) all human beings, irrespective of race, creed or sex, have the right to pursue both their material well-being and their spiritual development in conditions of freedom and dignity, of economic security and equal opportunity;

(b) the attainment of the conditions in which this shall be possible must constitute the central aim of national and international policy;

(c) all national and international policies and measures, in particular those of an economic and financial character, should be judged in this light and accepted only in so far as they may be held to promote and not to hinder the achievement of this fundamental objective;

(d) it is a responsibility of the International Labour Organization to examine and consider all international economic and financial policies and measures in the light of this fundamental objective; ...

III

The Conference recognizes the solemn obligation of the International Labour Organization to further among the nations of the world programmes which will achieve:

(a) full employment and the raising of standards of living;

(b) the employment of workers in the occupations in which they can have the satisfaction of giving the fullest measure of their skill and attainments and make their greatest contribution to the common well-being;

(c) the provision, as a means to the attainment of this end and under adequate guarantees for all concerned, of facilities for training and the transfer of labour, including migration for employment and settlement;

(d) policies in regard to wages and earnings, hours and other conditions of work calculated to ensure a just share of the fruits of progress to all, and a minimum living wage to all employed and in need of such protection; 
(e) the effective recognition of the right of collective bargaining, the cooperation of management and labour in the continuous improvement of productive efficiency, and the collaboration of workers and employers in the preparation and application of social and economic measures;

(f) the extension of social security measures to provide a basic income to all in need of such protection and comprehensive medical care;

(g) adequate protection for the life and health of workers in all occupations;

(h) provision for child welfare and maternity protection;

(i) the provision of adequate nutrition, housing and facilities for recreation and culture;

(j) the assurance of equality of educational and vocational opportunity....

\section{Notes}

1. Do the principles listed in the 1944 Declaration continue to be relevant? Think of the laws and public policies of a country you are familiar with. How do they measure up against the grand aspirations of the Declaration of Philadelphia? While most of the Philadelphia Declaration's goals are germane today, the document does not offer guidance on the mechanisms for achieving them. For example, the Declaration's aims are not tied directly to the adoption of particular conventions. This first ILO Declaration, with its far-reaching ambitions, and the absence of a road map for accomplishing them, stands in contrast with the more narrow and pragmatic 1998 Declaration on Fundamental Principles and Rights at Work, which is excerpted below. Broader aims, however, are discernible in the third ILO Declaration, the 2008 Declaration on Social Justice for a Fair Globalization, also covered below. After reviewing all three Declarations, query whether the ILO has today circled back to the expansive view of its role first set forth in the Philadelphia Declaration.

2. What kind of instrument is the Philadelphia Declaration? It is not considered a treaty. It is an annex to the ILO Constitution. Do its text and placement give guidance on the Declaration's effect on member countries? Article V of the Declaration states "that the principles set forth in this Declaration are fully applicable to all peoples everywhere...." ILO Constitution, Annex, Art. V. Professor Charles Morris argues that ILO membership commits the member states to an affirmative obligation to further the Declaration's objectives, a conclusion he believes was later confirmed by the 1998 ILO Declaration on Fundamental Principles and Rights at Work. Charles J. Morris, The Blue Eagle at Work: Reclaiming Democratic Rights in the American WORKPLACE 142 (2005).

3. As noted in Chapter 1, human rights are traditionally conceptualized as falling into two categories: (1) civil and political rights; and (2) economic, social, and cultural rights. Does the Philadelphia Declaration 
contain references to both types of rights? How would you describe the 1944 Declaration's treatment of the relationship between civil and economic rights?

4. An interesting feature of the Declaration of Philadelphia is Article III's objective of furthering national programs of full employment. One such ultimately unsuccessful national effort was the Full Employment Act of 1945, which sought to create in the United States an entitlement to fulltime employment and a corresponding obligation on the part of the federal government to maintain conditions to make the entitlement a reality. Its sponsors, influenced by writings of economist John Maynard Keynes, believed that business cycles of boom and bust were inevitable, could be catastrophically socially disruptive, and were capable of stabilization through a method known as "compensatory finance." As described by economist G. J. Santoni:

Section 3 [of the Act] laid out a formula for the federal government to follow in pursuing this goal. The formula required the President of the United States to submit a national budget to Congress at the beginning of each regular session. The budget was to contain a forecast of both the level of output necessary to generate full employment over the next year and the level of output that was likely to result if government did not intervene. If the projected level of output was less than the level necessary for full employment, the President was required to recommend legislation that would produce a big enough deficit in the federal government's budget to raise output to the full employment level. If the relationship between the two output forecasts were reversed, the President was required to recommend legislation that would result in a budget surplus big enough to reduce output to the full employment level.

G. J. Santoni, The Employment Act of 1946: Some History Notes, Federal Reserve Bank of St. Louis, Nov. 1986, 5, 9, available at http://research. stlouisfed.org/publications/review/86/11/Employment_Nov1986.pdf. The bill was attacked as un-American and socialistic. Subsequent amendments eliminated the right to full employment, the federal government's obligation to create conditions conducive to full employment, and the requirement of budgeting through compensatory finance. Id. at 11. The bill passed as the Employment Act of 1946. Id. at 12. The Humphrey/Hawkins Bill of 1976, an attempted revival of the central aspects of the 1945 bill, fared no better than its predecessor. Id. at 15 .

\section{The ILO in the Post-War Period}

Sir Bob Hepple identifies decolonization and the Cold War as the two main challenges confronting the ILO in the period following the Second World War. The former more than tripled the ILO's membership in a little over 50 years, taking it "[f] rom an elite of 52 mainly western industrial states in 1946" to its 
present composition of 183 member nations, many of which are poor, developing countries. Hepple notes:

This mass admission of developing countries had profound repercussions. Their main preoccupation was with technical co-operation, such as assistance with the drafting of labour codes, which would help them to claim compliance with international standards although the reality was often much different.

Hepple, supra, at 34. The developing nations also put increased pressure on the agency for flexibility in standard setting, and emphasized political issues like the activities of multinational corporations and states whose policies they deemed objectionable, such as those of Israel and the apartheid regime of South Africa. Id.

The Cold War, in turn, hampered the ILO's functioning due to strife between Western and Communist nations. Western countries argued that the ILO's principle of tripartism, which requires member countries to staff their delegations not only with government functionaries but also with independent workers' and employers' representatives, was threatened by the Soviet Union and its allies. Those countries, after all, had governments that neither permitted independent labor organizations nor private employment. Id. When ILO committees ruled that practices of the Communist countries, such as the "trade union monopoly, ... and rules concerning 'social parasitism," violated the ILO's conventions on freedom of association and forced labor, the Communist bloc countries leveled charges of Western bias at the ILO's supervisory machinery and sought to change it. Id.

During the Cold War, the United States, which waited to join the ILO until 1934, grew increasingly disenchanted with the organization. From the U.S. perspective, the agency had become too politicized. The United States took particular issue with the ILO's denunciations of South Africa and Israel, the ILO's criticism of the United States for its involvement in Vietnam, its approval of observer status for the Palestine Liberation Organization, and its perceived willingness to disregard the Soviet Union's record on human rights violations. In 1977, the United States withdrew from the ILO, citing, inter alia, these issues but vowing to return when its concerns were effectively addressed. As a country that contributed 25 percent of the ILO's budget, the U.S. withdrawal represented a means of applying political and economic pressure to the agency. By 1980, the United States sensed enough movement on some of its concerns to rejoin the ILO. Stephen I. Schlossberg, United States' Participation in the ILO: Redefining the Role, 11 Comp. LAB. L.J. 48, 68-71 (1989).

In 1984, the ILO, acting on a complaint of the International Confederation of Free Trade Unions (ICTWU), reported on Poland's dissolution of the free trade union Solidarność as a violation of freedom of association. This watershed event "sent shockwaves not just through the Soviet-dominated countries of Central and Eastern Europe but throughout the world." John P. Windmuller, Stephen K. Pursey \& Jim Baker, The International Trade Union Movement, in Comparative Labour LaW and Industrial Relations in IndustriALized MARKet EConomies 71, 91 (10th ed., Roger Blanpain ed., 2010). The ILO's 
contribution in safeguarding union rights in Poland during this period, and striking a blow against the concept of Communist Party control over organized labor, is widely acknowledged. Oliver Clarke, Greg J. Bamber \& Russell D. Lansbury, Conclusions: Towards a Synthesis of International and Comparative Experience in Employment Relations, in InTERnATIOnAL AND Comparative Employment Relations 294, 318 (3d ed., Greg J. Bamber \& Russell D. Lansbury eds., 2003). In the end, the collapse of the Soviet Union and the overthrow of Communism in Eastern Europe saw an end to that particular brand of ideological warfare within the ILO.

The end of the Cold War also prompted the ILO to reevaluate its mission, key values, and end results. Bellace, supra, at 12-13. Critics challenged an approach that emphasized the adoption and ratification of conventions, noting low ratifications of newer conventions and the accumulation of older conventions perceived as obsolete. Id. at 13. In response, the ILO Director-General in 1994 presented a strategy for the agency focusing on seven foundational conventions, which form the basis of the four fundamental human rights articulated in the Declaration on Fundamental Principles and Rights at Work, adopted by the ILO's International Labour Conference in 1998. ILO member countries, even those that have not ratified the presently recognized eight fundamental conventions, must respect, promote, and realize these principles. Arturo Bronstein, International and Comparative Labour Law: Current Challenges 101 (2009).

\section{ILO Declaration on Fundamental Principles and Rights at Work}

Adopted June 18, 1998, 37 I.L.M. 1233 (1998)

Whereas the ILO was founded in the conviction that social justice is essential to universal and lasting peace;

Whereas economic growth is essential but not sufficient to ensure equity, social progress and the eradication of poverty, confirming the need for the ILO to promote strong social policies, justice and democratic institutions; ...

Whereas, in seeking to maintain the link between social progress and economic growth, the guarantee of fundamental principles and rights at work is of particular significance in that it enables the persons concerned to claim freely and on the basis of equality of opportunity their fair share of the wealth which they have helped to generate, and to achieve fully their human potential;

Whereas the ILO is the constitutionally mandated international organization and the competent body to set and deal with international labour standards, and enjoys universal support and acknowledgement in promoting fundamental rights at work as the expression of its constitutional principles;

Whereas it is urgent, in a situation of growing economic interdependence, to reaffirm the immutable nature of the fundamental principles and rights 
embodied in the Constitution of the Organization and to promote their universal application;

The International Labour Conference,

1. Recalls:

(a) that in freely joining the ILO, all Members have endorsed the principles and rights set out in its Constitution and in the Declaration of Philadelphia, and have undertaken to work towards attaining the overall objectives of the Organization to the best of their resources and fully in line with their specific circumstances;

(b) that these principles and rights have been expressed and developed in the form of specific rights and obligations in Conventions recognized as fundamental both inside and outside the Organization.

2. Declares that all Members, even if they have not ratified the Conventions in question, have an obligation arising from the very fact of membership in the Organization, to respect, to promote and to realize, in good faith and in accordance with the Constitution, the principles concerning the fundamental rights which are the subject of those Conventions, namely:

(a) freedom of association and the effective recognition of the right to collective bargaining;

(b) the elimination of all forms of forced or compulsory labour;

(c) the effective abolition of child labour; and

(d) the elimination of discrimination in respect of employment and occupation....

4. Decides that, to give full effect to this Declaration, a promotional follow-up, which is meaningful and effective, shall be implemented in accordance with the measures specified in the annex hereto, which shall be considered as an integral part of this Declaration.

5. Stresses that labour standards should not be used for protectionist trade purposes, and that nothing in this Declaration and its follow-up shall be invoked or otherwise used for such purposes; in addition, the comparative advantage of any country should in no way be called into question by this Declaration and its follow-up.

\section{Notes}

1. As noted above, prior to the adoption of the Declaration, seven conventions were identified as being fundamental; an eighth was adopted in 1999. Hepple, supra, at 57. Two of the fundamental conventions fall under each of the Declaration's four fundamental rights categories. These eight fundamental conventions are instruments that do not bind member states until they are ratified by them. 
2. Freedom of association and the right to collective bargaining are tied to two conventions: Convention No. 87 (Freedom of Association and Protection of the Right to Organise, 1948); and Convention No. 98 (Right to Organise and Collective Bargaining, 1949). Convention No. 87 provides:

Workers and employers ... shall have the right to establish and ... to join organisations of their own choosing. ... Each Member [State] ... undertakes to take all necessary and appropriate measures to ensure that workers and employers may exercise freely the right to organise.

Convention No. 98 provides:

Workers shall enjoy adequate protection against acts of anti-union discrimination in respect of their employment.... Measures... shall be taken ... to encourage and promote the full development and utilisation of machinery for voluntary negotiation between employers or employers' organisations and workers' organisations, with a view to the regulation of terms and conditions of employment by means of collective agreements.

Keep these two conventions in mind as you review the workplace laws of various national jurisdictions. Do those laws pass muster? As of July 2011, 150 countries have ratified Convention No. 87. In comparison, 160 countries have ratified Convention No. 98.

3. Convention No. 29 (Forced Labour, 1930) and Convention No. 105 (Abolition of Forced Labour, 1957) are the touchstones for the second fundamental right, the elimination of forced or compulsory labor. Convention No. 29 provides:

Each Member [State] ... undertakes to suppress the use of forced or compulsory labour in all its forms within the shortest possible period.... [T] he term forced or compulsory labour shall mean all work or service which is exacted from any person under the menace of any penalty and for which the said person has not offered himself voluntarily.

Convention No. 105 provides:

Each Member [State] ... undertakes to suppress and not to make use of any form of forced or compulsory labour as a means of political coercion or education ... as a method of mobilising and using labour for purposes of economic development; as a means of labour discipline; as a punishment for having participated in strikes; as a means of racial, social, national or religious discrimination.

You will note, inter alia, that Convention No. 29 is relevant to the Article 26 complaint filed against Myanmar discussed infra. Likewise, Convention No. 105 is at issue in the Article 24 representation filed against Senegal discussed below. As for ratifications, as of July 2011, Convention No. 29 has been ratified by 175 countries; Convention No. 105 has been ratified by 169 countries. 
4. The effective abolition of child labor category is tied to Convention No. 138 (Minimum Age, 1973) and Convention No. 182 (Worst Forms of Child Labour, 1999). Convention No. 138 provides:

Each Member [State] ... undertakes to pursue a national policy designed to ensure the effective abolition of child labour and to raise progressively the minimum age for admission to employment or work to a level consistent with the fullest physical and mental development of young persons.

Convention No. 182, which is excerpted in Chapter 1 and discussed in the notes following it, provides:

Each Member [State] which ratifies this Convention shall take immediate and effective measures to secure the prohibition and elimination of the worst forms of child labour as a matter of urgency.... [T] he term the worst forms of child labour comprises... all forms of slavery or practices similar to slavery, ... including forced or compulsory recruitment of children for use in armed conflict; the use, procuring or offering of a child for prostitution, for the production of pornography or for pornographic performances; the use, procuring or offering of a child for illicit activities, in particular for the production and trafficking of drugs ... work which, by its nature or the circumstances in which it is carried out, is likely to harm the health, safety or morals of children.

As of July 2011, Convention No. 138 has been ratified by 161 countries. Convention No. 182 has been ratified by 174 countries.

5. Finally, the elimination of discrimination obligation references Convention No. 100 (Equal Remuneration, 1951) and Convention No. 111 (Discrimination - Employment and Occupation, 1958). Convention No. 100 provides:

Each Member [State] shall, by means appropriate to the methods in operation for determining rates of remuneration, promote and, in so far as is consistent with such methods, ensure the application to all workers of the principle of equal remuneration for men and women workers for work of equal value.

Convention No. 111, which is at issue in the Individual Observation regarding India, infra, provides:

Each Member [State]... undertakes to declare and pursue a national policy designed to promote, by methods appropriate to national conditions and practice, equality of opportunity and treatment in respect of employment and occupation, with a view to eliminating any discrimination....

Note 1 following the Individual Observation regarding India excerpts Convention No. 111's definition of discrimination. In terms of ratifications, as of July 2011, 168 countries have ratified Convention No. 100. Convention No. 111 has been ratified by 169 countries. 
6. Sir Bob Hepple describes the chief effect of the 1998 Declaration's adoption as significantly boosting the number of ratifications of the eight fundamental conventions. Id. at 60. By July 2011, 135 countries had ratified all 8 fundamental conventions.

7. Situating the Declaration's adoption historically, Professor Brian Langille notes:

[T] he modern international consensus on the core labour rights took shape in the 1990s as a result of the international community's endorsement of the idea in a number of fora - . . . from the ILO's point of view most critically at the WTO [World Trade Organization] Singapore Ministerial of 1996. The context of that meeting was very much the large public debate about a [WTO] "social clause"... precisely to get some real teeth into the international labour standards regime.... [I]n its over-energetic efforts to expel the labour issue from its agenda and deliberations, the WTO membership and the Singapore Declaration ... used some very strong language to propel the issue back into the ILO's court by reasserting its views on the importance of the core rights dimension of globalization and the leading role of the ILO in managing that issue.

Brian A. Langille, Core Labour Rights - The True Story (Reply to Alston), 16 Eur. J. InT'L L. 409, 420-21 (2005) (hereinafter Langille, The True Story). To its credit, argues Langille, the ILO seized the opportunity, realized that there was a need to be met, and created the Declaration to meet it. $I d$. at 421 . For more information on the WTO Singapore Ministerial of 1996, including the opposition of developing nations to the adoption of a WTO "social clause," see Chapter 1, section C.1.c (The World Trade Organization and Labor Rights).

8. That member states may pledge fealty to the Declaration without ratifying the fundamental conventions raises the question of the relationship between the Declaration's core labor standards and the instruments used as their touchstones. Professor Philip Alston argues that while some linkage between the Declaration and the fundamental conventions is obviously contemplated, the content of the conventions cannot simply be read into the Declaration. Non-ratifying states would never have supported the adoption of the Declaration if it were seen as a back door way of binding them to the conventions. Philip Alston, "Core Labour Standards" and the Transformation of the International Labour Rights Regime, 15 Eur. J. INT'L L. 457, 490-95 (2004).

9. One possibility, which concerns Alston, is that the Declaration is nothing more than an aspirational policy statement that allows member states to escape the detailed prescriptions of legally binding conventions and yet claim adherence more generally to ILO standards. Id. at 490-95. Does this theory explain the enthusiasm of the United States for the Declaration even though it has ratified only two of the fundamental conventions? The two fundamental conventions ratified 
by the United States are Convention No. 105 on forced labor and Convention No. 182 on the worst forms of child labor.

10. Another point of controversy regarding the Declaration involves those standards considered fundamental human rights by some commentators but that were not enumerated as part of the ILO's core. By designating some standards as central, has the ILO thereby minimized the importance of other equally vital employment concerns? Professor Michael Zimmer advocates embracing decent work with a living wage as an ILO fundamental labor principle. Michael J. Zimmer, Decent Work with a Living Wage, in The Global Labour Market: From Globalization to Flexicurity, 65 Bull. Comp. Lab. Rels. 61-80 (Roger Blanpain \& Michele Tiraboschi eds., 2008). Similarly, Professor Sarah Cleveland argues that providing subsistence wages, protection from ultra-hazardous workplace conditions, and protection for migrant workers should be considered core labor standards. Sarah H. Cleveland, Why International Labor Standards?, in InTERNATIONAL LABOR Standards: Globalization, Trade, and Public Policy 129, 15659 (Robert J. Flanagan \& William B. Gould IV eds., 2003).

11. A succinct statement on the connection between occupational safety and health, on the one hand, and fundamental rights at work on the other, was made on June 29, 2008 in the Seoul Declaration on Safety and Health at Work, an instrument adopted at the world's first highlevel Safety and Health Summit, and signed by close to 50 high-level decision makers from around the world, including ILO Executive Director for Social Protection Assane Diop. Described subsequently by the ILO as a welcome and unprecedented document, the Declaration on Safety and Health at Work includes the following statement: "[T] he right to a safe and healthy working environment should be recognized as a fundamental human right." Seoul Declaration on Safety and Health at Work, June 29, 2008, available at http://www. ilo.org/wcmsp5/groups/public/—dgreports/—dcomm/documents/ statement/wcms_095910.pdf. The Declaration on Safety and Health at Work is not an ILO instrument. Nor does it definitively state that safe work is a human right. Might the Seoul Declaration be a step toward global recognition of such a right within the ILO?

12. Clearly, the Declaration, which is not a convention or a recommendation, is an interesting and important ILO initiative. Does it represent a trend away from legally binding conventions in favor of "softer" soft law tools such as declarations and voluntary codes of conduct? Professor Virginia Leary finds notable both the ILO's characterization of the Declaration as a "solemn commitment" by member states, and the instrument's follow-up procedure, which requires non-ratifying states to submit reports on their progress toward achieving core labor standards. Virginia A. Leary, "Form Follows Function": Formulations of International Labor Standards - Treaties, Codes, Soft Law, Trade Agreements, in International Labor Standards: Globalization, Trade, 
And Public Policy 179, 186 (Robert J. Flanagan \& William B. Gould IV eds., 2003).

13. Professor Langille sees the 1998 Declaration as a step toward solving the crisis that threatened to reduce the ILO to irrelevance. The ILO's traditional approach of promulgating detailed standards, embodied in conventions that either had low ratification rates or were ratified and then observed by many countries in the breach, is clearly untenable if the agency hopes to effect change on the ground. Langille, The True Story, at 425-26. By stating in general terms the fundamental principles that all nations must observe, and then working to help member states achieve them, the ILO can positively promote conditions of social justice that are a precondition for a nation's economic success. Id. at 434. Moreover, by promoting respect for core rights, conditions are created for the advancement of other non-core concerns such as minimum wages, maximum hours, and health and safety. Id. at 435 .

14. Since adopting the 1998 Declaration, the ILO has described its primary goal as that of securing "decent work" for all people. The four strategic objectives encompassed within the decent work program are (1) promoting rights at work; (2) creating actual employment opportunities of acceptable quality; (3) obtaining and enhancing social protection for the risk of job loss; and (4) promoting social dialogue, a term encompassing tripartism but also accounting for opportunities for workers' and employers' representatives to engage in formal or informal discussions without the presence of government. Juan Somavia, Report of the Director-General (ILO 1999).

\section{The ILO Tackles Globalization and the Great Recession}

The early years of the twenty-first century saw the ILO at work shaping the dialogue on the costs and benefits of globalization, and the need to better manage increasing economic integration among the world's nations. To that end, the ILO's World Commission on the Social Dimension of Globalization was formed in February 2002. Two years later, after exhaustive research, the 26-person Commission published its final report, A Fair Globalization: Creating Opportunities for All (ILO 2004). While acknowledging globalization's potential to generate vast economic gains, the Commission's report warned that many countries and most people were not better off under present systems of global economic governance.

Publication of the Commission's report also triggered self-reflection within the ILO, and a recognition that the organization needed to address its capacity to meet its traditional objectives, the relevance of its core message, and the efficacy of its practices. Francis Maupin, New Foundation or New Façade? The ILO and the 2008 Declaration on Social Justice for a Fair Globalization, 20 Eur. J. 
INT'L L. 823, 829-30 (2009). Discussions ultimately resulted in the adoption of the 2008 ILO Declaration on Social Justice for a Fair Globalization. As Director-General Juan Somavia put it, "Just as the Declaration of Philadelphia was a response in May 1944 to the challenges of post-war reconstruction, the new Declaration is an expression of the relevance of the responses social dialogue at its best can produce to today's challenges of globalization." Juan Somavia, Reply by the Director-General to the Discussion of His Report, Sept. 2, 2008 , at 3 .

\section{ILO Declaration on Social Justice for a Fair Globalization}

Adopted June 10, 2008, I.L.M. (2008)

\section{SCOPE AND PRINCIPLES}

The Conference recognizes and declares that:

A. In the context of accelerating change, the commitments and efforts of Members and the Organization to implement the ILO's constitutional mandate, including through international labour standards, and to place full and productive employment and decent work at the centre of economic and social policies, should be based on the four equally important strategic objectives of the ILO, through which the Decent Work Agenda is expressed and which can be summarized as follows:

(i) promoting employment by creating a sustainable institutional and economic environment in which:

— individuals can develop and update the necessary capacities and skills they need to enable them to be productively occupied for their personal fulfillment and the common well-being;

- all enterprises, public or private, are sustainable to enable growth and the generation of greater employment and income opportunities and prospects for all; and

- societies can achieve their goals of economic development, good living standards and social progress;

(ii) developing and enhancing measures of social protection - social security and labour protection - which are sustainable and adapted to national circumstances, including:

- the extension of social security to all, including measures to provide basic income to all in need of such protection, and adapting its scope and coverage to meet the new needs and uncertainties generated by the rapidity of technological, societal, demographic and economic changes;

— healthy and safe working conditions; and

- policies in regard to wages and earnings, hours and other conditions of work, designed to ensure a just share of the fruits of progress to all and a minimum living wage to all employed and in need of such protection; 
(iii) promoting social dialogue and tripartism as the most appropriate methods for:

- adapting the implementation of the strategic objectives to the needs and circumstances of each country;

— translating economic development into social progress, and social progress into economic development;

- facilitating consensus building on relevant national and international policies that impact on employment and decent work strategies and programmes; and

- making labour law and institutions effective, including in respect of the recognition of the employment relationship, the promotion of good industrial relations and the building of effective labour inspection systems; and

(iv) respecting, promoting and realizing the fundamental principles and rights at work, which are of particular significance, as both rights and enabling conditions that are necessary for the full realization of all of the strategic objectives, noting:

- that freedom of association and the effective recognition of the right to collective bargaining are particularly important to enable the attainment of the four strategic objectives; and

- that the violation of fundamental principles and rights at work cannot be invoked or otherwise used as a legitimate comparative advantage and that labour standards should not be used for protectionist trade purposes.

B. The four strategic objectives are inseparable, interrelated and mutually supportive. The failure to promote any one of them would harm progress towards the others. To optimize their impact, efforts to promote them should be part of an ILO global and integrated strategy for decent work. Gender equality and non-discrimination must be considered to be cross-cutting issues in the abovementioned strategic objectives.

C. How Members achieve the strategic objectives is a question that must be determined by each Member subject to its existing international obligations and the fundamental principles and rights at work with due regard, among others, to:

(i) the national conditions and circumstances, and needs as well as priorities expressed by representative organizations of employers and workers;

(ii) the interdependence, solidarity and cooperation among all Members of the ILO that are more pertinent than ever in the context of a global economy; and

(iii) the principles and provisions of international labour standards.

\section{Notes}

1. The new Declaration marks the third time the ILO has issued a major statement of principles and policies and should be read along with the 
Declaration of Philadelphia (1944) and the Declaration of Fundamental Principles of Rights at Work (1998). Together the three declarations provide a foundation and methodology by which the ILO implements its constitutional objectives. Juan Somavia, Director-General's Announcement, Aug. 13, 2008, at 1. The 2008 Declaration also underscores two key principles: (1) the universality of the ILO's Decent Work Agenda, which requires member states to pursue four objectives (employment, social protection, social dialogue, and fundamental principles and rights at work); and (2) the indivisibility of the four objectives such that "[f] ailure to promote any one ... hinders progress towards achieving the others." Id. at 2.

2. The 2008 Declaration positions "decent work" as a goal central to the ILO's work and to the social and economic policies of ILO member states. Yet when first articulated in 1999, "decent work" was an intentionally vague construct. Maupin, supra, at 838-39. Since the ILO's adoption of the 2008 Declaration, and the advent of the global economic crisis, which began in autumn 2008, “decent work" has gained conceptual clarity. Susan Bisom-Rapp, Introduction: Decent Work in a Post-Recessionary World, 15 EMP. RTs. \& EMP. Pol'y J. 1-2 (2011). From the beginning of and throughout the crisis, for example, the ILO made "decent work" the centerpiece of its recommended strategy, issuing numerous reports on how the concept can form the basis for sustainable recovery and job growth. $I d$.

3. Professor Janice Bellace argues that the connection between "decent work," as expressed in the 2008 Declaration, and the 1998 Declaration of Fundamental Principles and Rights at Work, is discovered by tracing the ILO's commitment to social justice back to its founding. The ILO's purposes and goals serve as a link between the human rights principles expressed in the 1998 Declaration and the proactive stance of the ILO's decent work program. Understood correctly, "decent work" describes "the conditions which must exist for workers to be able to enjoy the human rights guaranteed them. ..." Bellace, supra, at 27. Social justice requires rights in action not in the abstract; hence workers "are able to enjoy the observance of their rights only under conditions of 'Decent Work.'” Id. at 28.

4. In what way does the 2008 Declaration espouse broader goals than the 1998 Declaration? Do you think it harkens back to the 1944 Philadelphia Declaration's lofty aspirations? In what way is the 2008 Declaration more pragmatic than the Philadelphia Declaration? Do Professor Bellace's observations above assist in answering these questions?

5. The last of the 2008 Declaration's four strategic objectives invokes the 1998 Declaration's fundamental principles and rights at work. Can you tell whether the 2008 Declaration recommends adopting particular conventions to realize its aims? At the least, is there an implicit injunction to ratify the eight fundamental conventions? 
6. Note that the ILO's most recently adopted convention embraces the concept of decent work in its text. Convention No. 189 (Domestic Workers, 2011), which obligates ratifying countries to promote the fundamental rights of household workers, also requires member states to "take measures to ensure that domestic workers, like workers generally, enjoy fair terms of employment as well as decent working conditions and, if they reside in the household, decent living conditions that respect their privacy." Convention No. 189, Article 6. For a comprehensive treatment of the legal obstacles and solutions to sub-par conditions confronting those laboring in domestic service work, see, e.g., Peggie R. Smith, Work Like Any Other, Work Like No Other: Establishing Decent Work for Domestic Service Workers, 15 EmP. RTs. \& EmP. POL'y J. 159 (2011).

7. "Decent work" is useful as a lens for understanding many of the problems confronting the global workforce, including the challenges of older workers, see, e.g., Susan Bisom-Rapp, Andrew Frazer \& Malcolm Sargeant, Decent Work, Older Workers and Vulnerability in the Economic Recession: A Comparative Study of Australia, the United Kingdom and the United States, 15 EMr. RTs. \& EMP. Pol'y J. 43 (2011), and the difficulty of establishing a transnational union movement, see, e.g., Michael J. Zimmer, Unions and the Great Recession: Is Transnationalism the Answer?, 15 Emp. RTs. \& EMP. Pol'y J. 123 (2011).

8. Professor Roger Blanpain notes that for over a decade the ILO's Decent Work Agenda has coincided with European Union social policy aims. Roger Blanpain, Decent Work in the European Union: Hard Goals, Soft Results, 15 EMP. RTs. \& EMP. POL'Y J. 29, 30. He nonetheless questions whether the EU has the means and formal competencies to achieve the lofty goals of its New European Strategy for Jobs and Growth, the socalled Europe Strategy 2020. Id. at 34-42.

9. Recently, Professor Brian Langille has expressed frustration with the extent to which the ILO continues to devote its limited resources to the promulgation of detailed, technical conventions and the legal supervisory machinery designed to enforce those instruments. Instead, he calls for a decisive shift to soft law, with conventions looking more like declarations, and the supervisory process shifting from an ethos of enforcement to one of enablement. Brian Langille, Imagining a Post "Geneva Consensus" Labor Law for Post "Washington Consensus" Development, 31 Comp. Lab. L. \& Pol’y J. 523 (2010) (hereinafter Langille, Post-Geneva Consensus).

10. Anne Trebilcock takes issue with Langille's characterization of ILO standard setting and enforcement. She argues that the adoption of the two most recent declarations, the 1998 Declaration and the 2008 Declaration, evidences the ILO's willingness to employ flexible initiatives to facilitate change and improvement. Anne Trebilcock, Putting the Record Straight about International Labor Standard Setting, 31 Comp. Lab. L. \& Pol’y J. 553, 565 (2010). Can the ILO be described 
as acting schizophrenically - maintaining a complex and expensive labor standards enforcement structure while simultaneously moving toward soft law mechanisms such as the 1998 and 2008 Declarations?

11. The 2008 Declaration's follow-up procedure requires a recurrent, thematic schedule of discussions at the annual International Labour Conference based on the Declaration's four objectives. In June 2010, the theme was employment promotion. As a prelude and to inform the discussion, the ILO's Committee of Experts prepared a General Survey of six conventions related to employment. ILO Committee of Experts, 2010 General Survey Concerning Employment Instruments (2010). For the 2011 International Labour Conference, the Committee of Experts created a General Survey of four conventions related to social security.

12. Relevant to the General Surveys, Professional Langille reports that in Canada, his home country, there is concern that the 2008 Declaration's follow-up procedures should "not add to already existing universal reporting requirements that are viewed as tiresome, unhelpful, and onerous." Langille, Post-Geneva Consensus, at 539. Anne Trebilcock, writing more optimistically, hopes that a new use of Article 19 of the ILO's Constitution, which requires member states to report on steps taken vis-à-vis unratified conventions, might lead, through the General Surveys, to a "more differentiated, inter-disciplinary, and gender-aware look into" the obstacles states face to ratification of specific conventions. Trebilcock, supra, at 559-60. With that in mind, this chapter continues with a discussion of ILO standard setting and structure.

\section{ILO Standard Setting and Structure}

Since its creation, the ILO has primarily set international labor standards by adopting conventions and recommendations, both of which may be thought of as forms of ILO "legislation." ILO legislation, however, differs from laws passed by national legislatures. At the time of ILO adoption, neither a convention nor a recommendation is binding on the member countries.

Nonetheless, while a national government need not accept the ILO's conventions, it is required to submit them for consideration to the competent authorities - generally its own legislature - within 18 months, and is subject to two reporting obligations. Hepple, supra, at 30. Article 19 of the ILO Constitution requires member countries to report on the steps they take to bring to the attention of the competent authorities the existence of new, unratified conventions. An additional reporting requirement under Article 19 requires member states, upon request, to detail their law and practice regarding a convention's subject, and to explain why ratification has been prevented or delayed. The member country responses to this provision are analyzed in a general survey of the convention topic. $I d$. at 48 . 
Once ratified by a member state without reservations, a convention is considered a multilateral treaty containing international obligations. Recommendations, in contrast, are designed to provide guidance only, need not be ratified by ILO member governments, and do not constrain their actions. Swepston, International Labour Law, at 143. This latter form of ILO legislation often supplements a particular convention, providing additional details to assist member countries in fashioning national policy.

Conventions and recommendations must be approved by two-thirds of the delegates attending the ILO's annual International Labour Conference (ILC), which functions as the quasi-legislative branch of the agency. The unique tripartite structure requires each member nation to send to the annual conference in June a four-person delegation comprised of two government officials, one representative of employers' interests, and one representative of organized labor, although many countries also send additional individuals as advisers.

A delegation's employer and worker representatives must be nominated with the agreement of the most representative organizations for those constituencies in its home country. The U.S. delegation includes a representative from the U.S. Council for International Business (USCIB), an organization comprised of over 300 multinational corporations, law firms, and business associations, and a delegate from the American Federation of Labor and Congress of Industrial Organizations (AFL-CIO), the voluntary federation of 57 national and international unions. ILC voting is by secret ballot, with delegates casting ballots individually. Thus, there is no need for the employer or worker representatives to vote in tandem with their government's representatives.

Setting the agenda for future ILCs, establishing the program and budget for the ILC to adopt, reviewing the status of various ILO projects, and electing the ILO Director-General are the tasks of the Governing Body (GB), which operates as the agency's board of directors or executive council. It too is tripartite in composition. Half of its 56 members are drawn from government, and there are 14 employers' representatives and 14 individuals representing workers. Ten of the government seats are reserved for representatives of ten countries deemed to be of "chief industrial importance," including the United States. Other members are elected every three years by the ILC, the government representatives on a geographically distributed basis, and the others by their respective constituencies. Swepston, International Labour Law, at 144. The GB meets three times a year.

The site of the ILO's overall activities is the agency's permanent secretariat, the International Labour Office (the "Office"), which is headquartered in Geneva, Switzerland. Almost 2,000 ILO employees work out of the Geneva headquarters and in the ILO's 40 field offices. Missions throughout the world are also undertaken by the up to 600 ILO experts staffing the agency's technical cooperation program. A Director-General, elected to a five-year term, is the head of the Office. The Office is also the headquarters of the ILO's substantial research, documentation, and publication activities. Potter, The ILO, at 85-7.

All three main ILO bodies - the ILC, the GB and the Office - play a role in setting international labor standards. Promulgation and adoption of a 
convention or recommendation is typically a two-year process. The process begins with the Office, which prepares a paper each year detailing possible subjects for action at future ILCs. In light of the paper, the GB may decide to place a particular subject on the agenda of an ILC to be held in two years' time. The Office then produces during the first year a global law and practice report and a questionnaire on the issue. Answers to the questionnaire, provided by the member nations and employer and labor groups, are the basis for draft conclusions and a report on the subject for discussion at a first ILC. At the ILC, a tripartite technical drafting committee amends the draft conclusions, conducts discussions and prepares a new report with conclusions that is submitted to the conference for approval. Once the report is approved, the ILC places the matter on the agenda for the next conference.

The report that emerges from discussions at the first conference is used by the Office to prepare a draft of the proposed instrument - a convention or a recommendation. The draft instrument is sent for comments by member governments, workers, and employers. These comments are used to prepare a final report and draft convention or recommendation, which is sent to member governments in advance of the ILC, and will be discussed, possibly amended, and ultimately voted upon at the second conference. $I d$. at 85-10-85-11. Once adopted by the ILC, a convention enters into force when two member countries ratify it.

As of June 2011, the ILO had adopted 189 conventions and 201 recommendations. The subjects covered by this international labor code include (1) freedom of association and the right to organize; (2) the abolition of forced labor; (3) protection from discrimination in employment; (4) child labor; (5) general employment matters; (6) conditions of work; (7) occupational safety and health; (8) the employment of women; (9) older workers; (10) migrant workers; (11) seafarers; and (12) labor administration, including inspection and the compilation of statistics. Swepston, International Labour Law, at 151-64. The most recently adopted convention, Convention No. 189 (Domestic Workers, 2011), and its accompanying Recommendation No. 201 (Domestic Workers, 2011) were adopted on June 16, 2011 by an overwhelming majority of ILO ILC delegates.

Although the depth and breadth of the ILO's corpus juris is impressive, some commentators query whether there are too many standards of questionable quality and relevance. Creighton, supra, at 257-59; Efren Córdova, Some Reflections on the Overproduction of International Labour Standards, 14 ComP. LAB. L.J. 138 (1993). Also of concern are the uneven ratification rates among conventions and countries. Some conventions have high levels of ratification while the vast majority receives little attention. Potter, The ILO, at 85-12. Moreover, member states vary considerably in their receptivity to ratification. Unlike most of its industrial counterparts, for example, the United States has ratified only 14 conventions, 2 of which are no longer in force. The U.S. ratification rate is one of the lowest in the world.

The ILO's initiative to revise and integrate its conventions acknowledges and responds to criticism that the proliferation of ILO labor standards has 
proven counterproductive for the agency. Over time, the ILO has engaged in less standard setting through the adoption of conventions. Sir Bob Hepple notes that in the ILO's first two decades, a little over three conventions were adopted each year. In contrast, from 1997-2004, only five conventions were adopted - none in 1998, 2002, and 2004. Hepple, supra, at 35.

\section{ILO Monitoring and Member Nation Compliance}

International labor standards are enforced by the ILO in two main ways: through the examination of reports and through the consideration of complaints. As noted above, conventions do not bind the member states unless they are ratified. Once ratified, however, the member country must maintain its national law and practice in conformity with the convention, which is considered a treaty. In some countries, ratification makes the convention part of national law, enforceable at the national level. Most ILO conventions are not drafted as self-executing, however, and instead require supplementary enacting legislation to be passed by the member country's legislature to bring about a direct national effect. Swepston, International Labour Law, at 162.

Article 22 of the ILO Constitution sets forth the obligations of all member states that ratify conventions:

Each of the Members agrees to make an annual report to the International Labour Office on the measures which it has taken to give effect to the provisions of Conventions to which it is a party. These reports shall be made in such form and shall contain such particulars as the Governing Body may request.

ILO Constitution, Article 22.

Although the express wording of Article 22 refers to an annual report, in practice the intervals in which the reports on various conventions are due are longer. Typically, reports are requested at two- or five-year intervals. Hepple, supra, at 48. Eight fundamental conventions that are the touchstones of the Declaration on Fundamental Principles and Rights at Work generally require reporting every two years. So too do four so-called priority conventions covering labor inspection (No. 81), employment policy (No. 122), labor inspection in agriculture (No. 129), and tripartite consultation at the national level (No. 144). Reports on all other ratified conventions are due every five years. Potter, The ILO, at 85-17-85-18. In November 2009, the Governing Body decided to increase to three years the reporting cycle for the fundamental and priority conventions but to leave the cycle intact for other conventions at five-year intervals. Implementation of this change, as well as grouping conventions for reporting purposes by subjects keyed to the four strategic objectives of the Declaration on Social Justice, is expected in 2012. General Report of the Committee of Experts on the Application of Conventions and Recommendations, 2011, at 29. 


\section{Committee of Experts on the Application of Conventions and Recommendations}

Article 22 reports are reviewed by the ILO's Committee of Experts on the Application of Conventions and Recommendations (CEACR), a body of at present 20 distinguished individuals, including judges, academics, and lawyers, who meet once a year in December. Approximately 2,000 reports are reviewed annually. The CEACR also reviews submissions from employer and workers groups, and may examine national law, court decisions, collective bargaining agreements, and other relevant texts. Potter, The ILO, at 85-19. A country deemed to fall short of full compliance with a ratified convention may receive from the CEACR a "direct request" soliciting additional or clarifying information on points of concern. Another mechanism by which the CEACR makes known its initial conclusions about convention noncompliance is by issuing "observations" in its annual report to the Conference Committee on the Application of Standards, a tripartite committee of the ILC that meets each June during the annual conference. The observations are also sent to the countries whose actions prompt them.

\section{CEACR: Individual Observation Concerning Convention No. 111, Discrimination (Employment and Occupation)}

$$
1958 \text { India (ratification: 1960) Published: } 2005
$$

Discrimination on the basis of social origin

1. In its 2002 observation, the Committee had referred to a communication from the [International Confederation of Free Trade Unions] ICFTU dated 2 September 2002 and to the Government's reply, which had been received during the Committee's session, on 3 December 2002. The Committee notes that an additional reply was received on 19 December 2002.

2. The communication of the ICFTU referred to the practice of manual scavenging, i.e. the removal of human and animal excreta from public and private latrines and open sewers. Manual scavenging is performed almost exclusively by Dalits (also known as untouchables) and according to government statistics, an estimated 1 million Dalits in India are manual scavengers. Women clean public latrines daily, removing the excrement with brooms and small tin plates and piling it into baskets which are carried on the head to faraway locations. Manual scavengers may also be engaged in underground sewage work, or in cleaning faeces from the railway systems, or in the disposal of dead animals. They work for state municipalities or for private employers. They are exposed to the most virulent forms of viral and bacterial infections, including tuberculosis. They may be paid as little as 12 rupees (US\$0.30) a day, for unlimited hours. Sometimes, they do not receive their pay.

3. According to the ICFTU, the allocation of labour on the basis of caste is a fundamental part of the caste system. Within the caste system, Dalits, who are considered "polluted" from birth, are assigned, through threats and coercion, 
tasks and occupations which are deemed ritually polluting by other caste communities, such as scavenging. Refusal to perform such tasks can lead to physical abuse, social boycott and exclusion from any other form of employment. This practice is described as clearly discrimination on the basis of social origin, as defined in Article 1 of the Convention.

4. The ICFTU alleges that, although legislation was enacted in 1993 to prohibit the employment of manual scavengers and the construction of dry latrines and funds exist for the construction of flush latrines and the rehabilitation of scavengers under a government national scheme, the employment of Dalits as manual scavengers continues throughout India. ...

5. The ICFTU submits that the Government of India has failed to fulfil (sic) its obligation under Article 2 of the Convention to pursue a policy to eliminate discrimination in employment, and its obligation under Article 3(d) to implement this policy in respect of employment under the direct control of a national authority....

6. In its reply dated 2 December 2002, the Government states that the eradication of manual scavenging is a matter of priority concern for the Government of India. It recognizes that manual scavenging still exists in certain pockets, due mainly to unchanged societal structures and mores. In order to resolve the problem of dry latrines, the Government has enacted a central legislation - the Employment of Manual Scavengers and Construction of Dry Latrines (Prohibition) Act, 1993, which came into force in 1997 - and it has made every effort to implement the Act in full earnest. ...

[The observation notes that the Government referenced two programs aimed at converting dry latrines into low-cost flush latrines, and providing alternative employment to "liberated scavengers." Under the programs, over 437,000 scavengers have been liberated and over 154,000 trained for alternative occupations.]

10. The Committee notes that in the practice of manual scavenging, persons belonging to a certain social group called the Dalits, are usually engaged on account of their social origin. This constitutes discrimination, as defined in Article 1, paragraph 1(a), of the Convention.

11. The Committee takes note of the Government's statement that the eradication of manual scavenging in the country is a matter of priority concern for the Government. It notes that the Employment of Manual Scavengers and Construction of Dry Latrines (Prohibition) Act, 1993, punishes the employment of persons for manually carrying human excreta and the construction or maintenance of dry latrines with imprisonment and/or a fine, and that a number of schemes have existed for a number of years for the construction of flush latrines and the liberation and rehabilitation of manual scavengers.

12. The Committee notes with concern that despite those measures, manual scavenging continues to be used in large parts of the country and large numbers of men and women have still to perform degrading tasks by reason of social origin and economic circumstances in inhuman conditions, in contravention of the Convention. The Committee expresses the hope that the Government will step up its efforts to ensure the prompt elimination of this 
practice and the access of the persons involved to other, more decent, jobs. In particular, the Committee requests the Government:

— to take measures to ensure that the state, local and railway authorities apply and enforce the prohibitions contained in the Employment of Manual Scavengers and Construction of Dry Latrines (Prohibition) Act, 1993, and that the penalties provided for their violation are effectively imposed (please provide indications on the number of prosecutions engaged and the number and nature of penalties imposed);

- to evaluate the effectiveness of the existing schemes for the construction of flush latrines and the rehabilitation of manual scavengers, taking into account the reports and recommendations of the competent organs including the National Commission for Safai Karamcharis [the official name for manual scavengers] and the National Commission on Scheduled Castes and Tribes; and

- to launch and/or expand public awareness programmes for the population and educational and training programmes for the authorities involved, in order to promote the changes in mentalities and social habits which are necessary to bring about the elimination of manual scavenging.

The Government is requested to provide information on the concrete measures taken with regard to these matters....

\section{Notes}

1. The CEACR specifically references Article 1, paragraph 1(a) of C. 111, the Discrimination (Employment and Occupation) Convention, which, true to its name, prohibits employment discrimination. Article 1, paragraph 1 of the Convention provides:

1. For the purpose of this Convention the term discrimination includes

a. any distinction, exclusion or preference made on the basis of race, colour sex, religion, political opinion, national extraction or social origin, which has the effect of nullifying or impairing equality of opportunity or treatment in employment or occupation;

b. such other distinction, exclusion or preference which has the effect of nullifying or impairing equality of opportunity or treatment in employment or occupation as may be determined by the Member concerned after consultation with representative employers' and workers' organisations, where such exist, and with other appropriate bodies.

Discrimination (Employment and Occupation) Convention, June 25, 1958, ILOLEX C111, available at http://www.ilo.org/ilolex/english/ convdisp1.htm. Paragraph 10 of the 2005 observation notes that the Dalits are a social group engaged in the occupation of manual 
scavenging because of their social origin. The Committee also concludes that the plight of the Dalits in this case constitutes discrimination on the basis of social origin in violation of the Convention. Is the objection of the CEACR to the relegation of a particular social group to this occupation or to the inhuman nature of the work itself?

2. In 1950, the concept of untouchability was abolished by the Constitution of India. What factors explain the persistence of a despised caste and the assignment of its members to the worst jobs in the Indian economy? A recent report published by the Robert F. Kennedy Center describes the failure of Indian law to eradicate widespread practices associated with untouchable status, including the segregation of religious worship, drinking water, housing, and seating in school. Navsarjan Trust and RFK Center, Understanding Untouchability: A Comprehensive Study of Practices and Conditions, Jan. 27, 2010, available at http://www.rfkcenter.org/untouchability. For information about the social and legal status of the Dalits, see Chapter 13, section D ("Equal Opportunities" for the Scheduled Castes, Scheduled Tribes and Other Backward Classes). See also Ravi Shankar Shukla, Manual Scavenging: The Story of Untouchables Among Untouchables, Nov. 6, 2009, paper available via the Social Science Research Network.

3. In its 2005 observation concerning India's noncompliance with Convention No. 111, the CEACR provided that nation with a list of steps it wanted India to take to increase the pace at which manual scavenging is eliminated. The CEACR also expected to receive from India an update on the measures taken to address this exploitive and discriminatory occupation. Making a request, however, does not guarantee that the committee will receive the information. Indeed, in a part of the observation not reproduced above, the CEACR noted that its 2002 observation on sex discrimination in India had included a request that the government provide statistical data on the educational gap between Indian boys and girls, statistics on female labor force participation, and information on the status of the National Policy for the Empowerment of Women, the body that monitors programs aimed at the economic empowerment of women. Instead of supplying the requested data, the Indian government responded that the information will be supplied "as and when it becomes available." CEACR: Individual Observation Concerning Convention No. 111, Discrimination (Employment and Occupation), 1958 India (ratification: 1960) Published 2005, at 16.

4. The CEACR's 2010 observation concerning India's noncompliance with Convention No. 111 regarding the Dalits notes that "the Government has continued to take measures towards the elimination of the practice of manual scavenging. However, the Committee expresses serious concern that, despite these efforts, thousands of Dalit men and women still find themselves trapped in this inhumane and degrading practice. The Committee is particularly concerned at the apparent weak enforcement of the Employment of Manual Scavengers and Construction of 
Dry Latrines (Prohibition) Act of 1993, and that the practice even continues in employment under the Government's authority contrary to Article 3(d) of the Convention." CEACR: Individual Observation Concerning Convention No. 111, Discrimination (Employment and Occupation), 1958 India (ratification: 1960) Published 2010, at 425 (emphasis in original).

5. Monitoring through reporting may seem an odd enforcement mechanism to those used to quasi-judicial or judicial proceedings involving the possibility of concrete sanctions. The ILO's reporting procedures, in contrast, rely on moral suasion and public shaming. Professor Brian Langille characterizes the ILO supervisory mechanism as "a decidedly soft law system." Langille, The True Story, at 413. Yet while the enforcement techniques lack "teeth" in the sense of providing for monetary sanctions, one must remember that ratified conventions are binding legal instruments. They thus may be distinguished from purely voluntary tools, such as some international declarations, guidelines, or corporate codes of conduct.

6. The number of Article 22 reports received from member states is substantially less than the number requested by the CEACR. For example, the CEACR requested that a total of 2,745 Article 22 reports be submitted to it by September 1, 2010. It received 1,866 reports or only 67.98 percent of the reports requested. General Report of the Committee of Experts on the Application of Conventions and Recommendations, 2011, at 34. Moreover, many of the reports received are submitted late. "[B]y 1 September 2010, the proportion of reports received was only 31.4 per cent." $I d$. at 93 . Lateness in submitting reports hampers the functioning of the supervisory process, making it impossible to consider some cases, which then must be deferred for examination prior to the next year's meeting of the ILC.

7. Since 1964, the CEACR has compiled a list of cases in which member countries exhibit progress in bringing their laws and practice into compliance with ratified conventions after receiving committee comments. The 2011 report notes the CEACR's satisfaction that progress was made in 63 cases in 40 countries. The total list of such cases from 1964 through 2010 numbers 2,803. General Report of the Committee of Experts on the Application of Conventions and Recommendations, 2011, at $94-65$.

\section{Conference Committee on the Application of Standards}

After reviewing the annual CEACR report, the Conference Committee on the Application of Standards (CCAS), the tripartite committee of the ILC that meets during the annual conference, typically considers about 25 of the most serious cases detailed. The CCAS then conducts detailed discussions 
with the governments involved in those cases, and adopts conclusions in its annual report to the ILC. Potter, The ILO, at 85-20.

Many of the cases involve factual circumstances that are shocking. For example, the 2005 CCAS report provides a synopsis of the discussion involving Colombia's violation of Convention No. 87, Freedom of Association and Protection of the Right to Organize. At the start of the discussion, a government representative from Colombia addressed the progress his country had made in reducing violence directed against labor union leaders:

... In the specific case of labour union leaders, whereas in 2002, unfortunately 205 had been murdered, in 2004 the number of murdered trade unionists had been 89 , representing a reduction of 56.58 per cent....

According to the report of the National Prosecutor's Office for the period 2002-04 on cases currently under investigation for offences of homicide, in which the victim was associated with a labour union, there had been 36 preventive detentions, 21 charges, four sentences and 131 investigations, which amounted to significant progress in comparison with ten years ago.

Report of the Conference Committee on the Application of Standards, Provisional Record 22, Part II, Ninety-Third Session, Geneva, 2005, Convention 87, Freedom of Association and Protection of the Right to Organise, 1948 Colombia (ratification: 1976).

Despite this progress, the CCAS condemned in the strongest terms all such acts of violence, and concluded that "organizations of workers and employers could exercise their activities in a free and meaningful manner only in a climate that was free from violence. ..." Id. The Colombian government was exhorted to redouble its efforts to put an end to a situation that obviously presented a great obstacle to the realization of the rights guaranteed by Convention No. 87 . Finally, the CCAS decided that a high-level tripartite visit to Colombia by ILO representatives was necessary. $I d$.

Conditions affecting Colombian trade unionists clearly fit within the category of the CCAS's most serious cases. Indeed, Colombia's record in this regard, inter alia, for years stymied congressional ratification of the U.S.Colombia Trade Promotion Agreement. Len Bracken, Obama, Santos Tout Colombian Action Plan; Steelworkers, Teamers Express Opposition, Daily Lab. Rep. (BNA), at A-8 (Apr. 7, 2011). Ultimately, progress by Colombia on labor rights concerns led to the trade agreement's passage. On October 21, 2011, President Obama signed legislation implementing the U.S.-Colombia free trade agreement. For information about the U.S.-Colombia Trade Promotion Agreement, see Chapter 6.

Some of the other cases categorized by CCAS as serious may strike students of international labor law as surprising and very revealing. The CCAS's consideration in 2005 of the United States' possible noncompliance with Convention No. 144, Tripartite Consultation (International Labour Standards), is such a case. See Tripartite Consultation (International Labour Standards) Convention, June 26, 1976, ILOLEX C144, available at http://www.ilo.org/ ilolex/english/convdisp1.htm. 
Article 2 of Convention No. 144 requires ratifying countries to "operate [national level] procedures which ensure effective consultations ... between representatives of the government, of employers and of workers" on ILOrelated activities. Id. Article 5 of the Convention requires that "consultation ... shall be undertaken at least once a year." Id. The AFL-CIO, in comments attached to a U.S. government report for the period from 2001 to 2004, alleged that under the Bush Administration the tripartite consultation process had ground to a halt. In an individual observation, the CEACR requested the U.S. government to provide information in its next report on the steps it has taken to ensure effective consultation and to resolve the issues raised by the AFL-CIO. Interestingly, the CCAS selected this case as one of the 25 most serious cases to come before it in 2005.

\section{Report of the Conference Committee on the Application of Standards, Provisional Record 22, Part II, Ninety-Third Session, Geneva, 2005, Convention No. 144, Tripartite Consultation (International Labor Standards)}

1976 United States (ratification: 1988)

A [U.S.] Government representative stated that the United States took its obligations under ratified Conventions very seriously....

She recalled that tripartite arrangements had been established in 1975 when the United States was contemplating withdrawal from the ILO. There had been tripartite consultation at the highest level on the decision to withdraw and, during the period of withdrawal, on whether and when to return. The mechanism was a Cabinet Level Committee that included the President of the AFL$\mathrm{CIO}$ and a representative from the United States Chamber of Commerce. Upon rejoining the ILO in February 1980, the United States formalized the Cabinet Level Committee as a federal advisory committee called the President's Committee on the ILO....

The President's Committee was the pinnacle of the tripartite mechanism and provided for consultation at the highest level. More continual consultation occurred through a staff-level consultative group and in the Tripartite Advisory Panel on International Labour Standards (TAPILS) that was created specifically to examine the legal feasibility of ratifying selected ILO Conventions. One of the first conventions that TAPILS had examined was Convention No. 144. ... The framework for tripartite consultations had not changed since.

The [U.S. government representative] pointed out that this was the first time that the Committee of Experts had expressed any concern at all about United States application of the Convention. The question, she noted, was whether tripartite consultations in the United States were effective. [The U.S. government representative described the Convention as a flexible promotional instrument that requires consultations but does not specify that they must take the form of a meeting.]

Turning to the factual issues of the case, [the U.S. government representative] stated that there had indeed not been a meeting of the 
President's Committee since May 2000. In fact, since the United States ratified Convention No. 144 in 1988, the President's Committee had met on only six occasions. This was because the President's Committee only met when warranted by ILO-related issues that required a decision at the highest level. . . . As a consequence, most ILO consultations were held less formally.

The observation also indicated that the TAPILS did not meet during the reporting period. [The U.S. government representative] announced that the Panel had met last month [May 2005] to begin reviewing Convention No. 185 on Seafarers' Identity Documents....

With regard to the Committee of Experts' observation that for the first time since 1991, the Government had not convened a full meeting of the consultative group in preparation of the 2004 ILO Conference, [the U.S. government representative] pointed out that the Department of Labor had in fact scheduled its usual full pre-Conference briefing but learned subsequently that a significant portion of the delegation, particularly from the AFL-CIO, could not attend. Consequently, the meeting had to be rescheduled at a time that could include the AFL-CIO, closer to the opening of the Conference, with more limited attendance... This year, the Government had again hosted a full tripartite meeting in preparation of the 2005 ILO Conference.

The [CCAS] Worker members recalled that Convention No. 144 set forth the obligation for ratifying States to establish, in accordance with national practice, effective tripartite consultations with respect to the matters concerning the activities of the ILO. To contravene these provisions or to interpret this instrument in a restrictive manner imperiled the credibility of trade unions as well as the efficiency of ILO standards. ... For the past three years, the Government had not convoked the President's Committee or the Tripartite Advisory Panel on International Labour Standards (TAPILS), the bodies intended to implement Convention No. 144.... The observation of the Committee of Experts had established that the Government had clearly ceased to be active in the tripartite process and had taken no action toward further ratifications of ILO standards....

The Worker member of India stated that this case was a clear violation of Convention No. 144. For the first time since 1991, the United States Government had not convened a full consultative group in 2004 in preparation for the Conference... This lack of this preparation was a violation of democratic norms and was unbecoming for a country which never failed to project itself as the champion of democracy....

The Government member of Cuba stated... [i]t was clear that greater attention should be focused on Governments that only ratified a small number of Conventions....

The Worker member of Pakistan stated that the United States, in its role as the leader of the developed world and as one of the states of chief industrial importance in the Governing Body, should play an exemplary role not only in the ratification of ILO Conventions but in their implementation in letter and spirit.... He concluded by noting that the United States often pressed for the ratification and implementation of fundamental Conventions in other 
countries. In the light of this, the United States should take the lead in ratifying and implementing such Conventions itself. ...

The Committee noted the statement made by the [U.S.] Government representative and the discussion that followed. The Committee noted that, in accordance with the Convention and the comments made by the Committee of Experts in its observation, the Government and the social partners should establish procedures to ensure effective consultations....

The Committee requested the Government to take all the appropriate measures to promote tripartite dialogue on international labour standards. The Committee hoped that the Government would provide information in its next report on the progress made to guarantee the holding in practice of tripartite consultations in a manner that was satisfactory for all the parties concerned.

\section{Notes}

1. Why did the CCAS select the U.S. tripartite consultation case for review in 2005 as one of the most serious cases? While Convention No. 144 is considered a "priority convention," perhaps the situation was addressable in a less public forum. The CEACR did produce an individual observation that was forwarded to the U.S. government. What more is gained by characterizing the case as among the most serious?

2. As noted above, the U.S. government convened the Tripartite Advisory Panel on International Labor Standards (TAPILS) in May 2005 to begin reviewing Convention No. 185 on Seafarers' Identity Documents, and also held a tripartite meeting of the full consultative group to prepare for the 2005 ILC. Is this evidence that the ILO's enforcement mechanism works?

3. Interestingly, while the United States, at 14 conventions, has one of the world's lowest ILO ratification rates, it is considered to be a high compliance nation; in other words, the CEACR has not often issued individual observations based on the U.S. government's actions regarding its ratified conventions. Hepple, supra, at 42. In contrast, the United Kingdom, France, Italy, Spain, Netherlands, Norway, and Finland all have ratified 80 or more conventions but are considered low-compliance member states. Id. at 40.

4. An obvious subtext in the case is the perceived hypocrisy of the United States in refusing to ratify most of the ILO's conventions, yet using the ILO's eight fundamental conventions, which act as references to the 1998 Declaration on Fundamental Principles and Rights at Work, as a touchstone for judging the labor standards of its trading partners, especially in the context of negotiating free trade agreements. Is there a different way to interpret U.S. actions in this respect?

5. The U.S. reluctance to ratify ILO conventions has been attributed to a number of factors. First, during the ILO's early decades, the U.S. labor 
movement's approach to securing worker rights centered mainly on voluntarily negotiating collective bargaining agreements. Excessive government involvement was seen as antithetical to workers' interests. Leary, supra, at 181.

6. Next, some U.S. policymakers and business people believe that extensive ratification of ILO conventions would "usurp the jurisdiction of Congress to establish a National labor policy, and the jurisdiction of the individual States to regulate labor matters traditionally within their authority." Statement by Senator Strom Thurmond, Examination of the Relationship Between the United States and the International Labor Organization, Hearing Before the Senate Committee on Labor and Human Resources, 99th Cong., 1st Sess., vol. 1, p. 5 (1985). Those espousing this view are especially concerned about ratifying conventions that would require changes in domestic labor and employment law. Edward E. Potter, A Pragmatic Assessment from the Employers' Perspective, in Workers' Rights as Human Rights 118, 134 (James A. Gross ed., 2003). Is this a valid concern? U.S. policy, even under presidential administrations favorably disposed toward the ILO, has been to consider ripe for ratification only those conventions that are clearly non-self-executing, and thus not directly enforceable as U.S. law in U.S. courts. Moreover, the conventions considered candidates for U.S. ratification are those that TAPILS concludes require no change in existing U.S. law.

7. Some tie the reticence of the United States to its unique system of labor market regulation, which tends to emphasize individual over collective rights, and is far more flexible and less protective of employee job security as compared with other industrialized nations. Lee Swepston, Closing the Gap Between International Law and U.S. Labor Law, in Workers' Rights as Human Rights 53, 55 (James A. Gross ed., 2003). The ILO's conventions are seen as in harmony with European approaches to labor and employment law, and out of step with those in the United States. Thomas B. Moorhead, U.S. Labor Law Serves Us Well, in Workers' Rights as Human Rights 136, 138 (James A. Gross ed., 2003).

8. Others ascribe the low U.S. ratification rate to American "lack of interest and knowledge of international organizations," and a preference for unilateralism. Leary, supra, at 181-82.

9. Even where U.S. law is clearly in compliance with an important fundamental convention, there has been little political will for ratification. As noted by the U.S. government representative in the U.S. tripartite consultation case:

With regard to Convention No. 111 [Discrimination (Employment and Occupation)], progress had been slow. On the basis of a finding by TAPILS that United States law and practice were in full conformity with its provisions, Convention No. 111 had been forwarded by the 
President in May 1998 to the United States Senate with a request for advice and consent to ratification. Since then, Convention No. 111 had consistently been on a list of treaties that the Executive Branch considered to deserve priority attention. The Senate, however, while apparently not disinclined to consider the Convention, had given precedence to treaties having a direct bearing on national security.

Report of the Conference Committee on the Application of Standards, Provisional Record 22, Part II, Ninety-Third Session, Geneva, 2005, Convention No. 144, Tripartite Consultation (International Labor Standards), 1976 United States (ratification: 1988). For his part, the U.S. CCAS worker member complained that ratification of Convention No. 111 was not a priority of the Bush Administration, and that he would like to see the administration actively lobbying the Senate to move on the matter. $I d$.

10. Might a change in presidential administration prompt progress toward U.S. ratification of Convention No. 111 and compliance with Convention No. 144? On May 4, 2010, Hilda Solis, President Obama's Secretary of Labor, hosted the first meeting of the President's Committee on the International Labor Organization in a decade. The committee decided to make ratification of Convention No. 111 [Discrimination (Employment and Occupation)] a priority and reviewed two maritime conventions. On May 20, 2010, TAPILS met for the first time since 2005. Among other things, TAPILS is developing a shortlist of ILO Conventions suitable for U.S. ratification. The CEACR noted with interest the reinvigoration of the U.S. tripartite consultative process. CEACR: Individual Observation Concerning Convention No. 144, Tripartite Consultation (International Labor Standards), 1976 United States (ratification: 1988), published 2011, at 489.

11. The Bureau of International Labor Affairs (ILAB) carries out the U.S. Department of Labor's international responsibilities. ILAB is the U.S. government's "primary point of contact with the ILO," and its activities include preparing U.S. government reports for submission to the international organization. Report of the Conference Committee on the Application of Standards, 2005 Convention No. 144: Tripartite Consultation (International Labor Standards), 1976 United States (ratification: 1988).

12. What are the costs to U.S. global influence of its policy and practice on ILO convention ratification? Would pursuing a more aggressive ratification policy jeopardize U.S. interests?

\section{Adversarial Procedures}

The ILO supervisory mechanism also has two forms of adversarial procedures. One involves the filing of representations. The other provides for the filing of complaints. 


\section{a. Filing Representations under Article 24}

Article 24 of the ILO Constitution allows workers' or employers' organizations to file representations to the GB that a particular member country is not effectively observing a convention it has ratified. Swepston, International Labour Law, at 164. If the representation is found receivable, the GB establishes a three-person tripartite committee to investigate the merits of the case, and make recommendations. The committee prepares a report for the GB, and the GB invites the member nation at issue to attend a meeting at which the case is discussed. Alternatives available to the GB in deciding how to dispense with the case include (1) adopt the report and refer the case to the regular supervisory process; (2) publish the report in order to increase the pressure for the nonconforming country to comply; or (3) refer the case to a Commission of Inquiry, a mechanism that will be described below. Potter, The ILO, at 85-22. The representations procedure has only been invoked on fewer than 100 occasions, but there has recently been a notable increase in the use of this device. Swepston, International Labour Law, at 164-65.

\section{Report of the Committee Set Up to Examine the Representation Made by the Senegal Teachers' Single and Democratic Trade Union (SUDES) Under Article 24 of the ILO Constitution Alleging Non-observance by Senegal of the Abolition of Forced Labor Convention}

1957 (No. 105) Published: 1997

\section{DECISION}

The Governing Body adopted the report of the tripartite committee. Procedure closed.

\section{A. Introduction}

1. By letter of 28 August 1995, the Senegal Teachers' Single and Democratic Trade Union (SUDES), referring to article 24 of the Constitution of the International Labour Organization, made a representation alleging the nonobservance by Senegal of the ... Abolition of Forced Labour Convention, 1957 (No. 105)....

\section{B. Examination of the Representation ...}

9. The SUDES alleges failure by the Government of Senegal to observe the Abolition of Forced Labour Convention, 1957 (No. 105), by virtue of its recruitment through a press advertisement of "1,200 education volunteers."

10. As regards the facts, the SUDES alleges that the Government's press advertisement ... specifies that it is aimed at young people who have at least the equivalent of the BFEM diploma and have "no short-term employment prospects." The purpose of this recruitment is among other things to "reopen over 500 classes that have been closed because no teacher is available" and "to 
halt the decline" in the school enrol[1]ment rate, but also "to combat unemployment and underemployment among young people." The advertisement explains the Government's strategy in this area by stating that "given the constraints facing the State," the Government is seeking to "launch a movement of young education volunteers" and, for the next four years, "to recruit 1,200 education volunteers for elementary classes each year, especially for children in Senegal's most backward areas." These young people, according to the advertisement, will "find work which makes good use of their intellectual, moral and physical potential," will "learn the profession of teacher," and will "receive a monthly scholarship of 50,000 CFA francs and free housing on the spot in backward areas." ...

13. As regards observation of the Abolition of Forced Labour Convention, 1957 (No. 105), the SUDES emphasizes that, under the terms of Article 1(b) of the Convention, any Member of the ILO which ratifies the Convention undertakes to suppress and not to make use of any form of forced or compulsory labour "as a method of mobilizing and using labour for purposes of economic development." According to the SUDES, this provision has not been observed by the Government of Senegal which specifies in its "advertisement" for "education volunteers" that it wishes to "mobilize" the potential for commitment of young people who have "no short-term employment prospects" in a "movement" which would contribute to the development of the country. According to the SUDES, the population groups targeted by the recruitment drive (unemployed graduates, young people without employment prospects) clearly show that economic constraints, the need to find work at all costs are the real "motivation" for these "volunteers." For them, there is no possibility of choice. Under such circumstances, using the term "volunteer" is inappropriate, since those recruited are forced by economic constraints to accept the offer....

\section{OBSERVATIONS AND COMMENTS BY THE GOVERNMENT ...}

17.... [T] $\mathrm{T}]$ Government observes that the country is facing severe economic difficulties at a time when it is required to face up to the challenge of providing education for all by the year 2000, in accordance with the commitments accepted at Jomtien. Those commitments of 1990, taken as a whole, confront it and other governments of developing countries with very difficult choices and necessitate alternative solutions other than tried and tested conventional models....

[The Government responded to SUDES's charges of political bias in the selection process by describing at length the system by which candidates were hired. It also noted that of the 32,595 candidates, 1,200 were selected.]

24. As regards observance of the Abolition of Forced Labour Convention, 1957 (No. 105), the Government states that the provisions of the Convention have not been infringed. There is no question of forced labour, still less of compulsory labour. The education volunteers are able to await developments. If they find other employment, they are released at their own request. If, on the other hand, they decide to pursue a career in teaching, they can continue with 
their training for four years and complete their voluntary work before being recruited by the public sector or local collectives....

\section{CONCLUSIONS ...}

27. Definition of forced or compulsory labour. The SUDES alleges nonobservance by the Government of Senegal of Article 1(b) of the Abolition of Forced Labour Convention, 1957 (No. 105), which has been ratified by Senegal. Pursuant to that provision, the Government has undertaken not to make use of any form of forced or compulsory labour as a method of mobilizing and using labour for purposes of economic development. The Convention does not define the concept of forced or compulsory labour. According to the established practice of the ILO's supervisory bodies the definition of the concept of forced labour contained in Article 2, paragraph 1, of the Forced Labour Convention, 1930 (No. 29) is generally valid and can thus also be used to determine what constitutes "forced or compulsory labour" within the meaning of the 1957 Convention, namely "all work or service which is exacted from any person under the menace of any penalty and for which the said person has not offered himself voluntarily." It was noted during the examination of the draft 1930 Convention by the International Labour Conference that the penalty in question did not necessarily have to take the form of a penal sanction, but could also take the form of the loss of any rights or privileges....

28. Economic constraints. The concept of forced or compulsory labour implies that the worker has not offered himself voluntarily for the work or service in question. In the case which is the subject of the present representation, the workers concerned responded to a public appeal directed at volunteers with certain qualifications. Of 32,595 candidates who came forward, 1,200 were selected. Without contesting the voluntary nature of the offer of service by the candidates responding to the appeal, the SUDES claims that the candidates were not free.... The Committee notes that the concept of economic constraint was at the heart of the conclusions drawn by ILO bodies concerning previous representations alleging non-observance of the Forced Labour Convention, 1930 (No. 29). It thus appears appropriate to identify the criteria on which those conclusions were based.

29. Precedents. The Committee set up by the Governing Body to examine the representation presented in 1983 by the National Trade Union Coordinating Council of Chile (CNS) under article 24 of the Constitution alleging non-observance by Chile of Convention ...29 ... examined the bearing of official employment programmes, namely, the "Minimum Employment Programme" (PEM) and the "Employment Programme for Heads of Household" (POJH), on the observance of the Forced Labour Convention, 1930 (No. 29). The Committee concluded that persons enrolled in these programmes "cannot be considered to enjoy freely chosen employment." In particular, the Committee took the view that "work carried out by many persons, paid for with excessively low wages and not offering the protection of the labour and social security legislation, can give rise to doubts concerning its 
voluntary nature, particularly when it involves not a temporary or emergency solution but a situation that tends to last....

30. Criteria regarding constraint by the Government. If the case submitted to the Committee for examination has certain similarities with those mentioned above (absence of better alternatives for the candidates, the hope of finding stable employment), there are a number of important differences that were taken into account by previous Committees, in particular the level of remuneration and benefits and the number of persons affected. In a case where an objective situation of economic constraint exists but has not been created by the Government, then only if the Government exploits that situation by offering an excessively low level of remuneration could it to some extent become answerable for a situation that it did not create. Moreover, it might be held responsible for organizing or exacerbating economic constraints if the number of people hired by the Government at excessively low rates of pay and the quantity of work done by such employees had a knock-on effect on the situation of other people, causing them to lose their normal jobs and face identical economic constraints.

31. This has not happened in the present case. Rather than "a large number of persons paid at excessively low rates," 1,200 people were selected from more than 30,000 candidates for the period beginning 1995, and their remuneration, according to the Government, is above that of student teachers in teacher training schools having broadly similar functions. ... In short, the Committee considers that economic constraints may in practice be such as to be conducive to forced labour. However, in the present case the Government could not be held responsible for having created or exacerbated economic constraints, nor for having exploited them by offering people who had no other options, employment on terms that would not normally be acceptable.

32. Conclusion. In the light of the above, the Committee concludes that the representation alleging non-observance by Senegal of the Abolition of Forced Labour Convention, 1957 (No. 105) is unfounded.

\section{Notes}

1. Why do you think the union brought a representation against the Senegalese government? One major concern, articulated subsequently by the union in an allegation before a joint ILO/United Nations Educational, Scientific and Cultural Organization (UNESCO) committee, is the potential for the Education Volunteers Program to undermine the status and working conditions of the teaching profession. The volunteers initially received a monthly stipend worth just a little over the Senegalese minimum wage, representing less than half of the monthly salary of a regular starting teacher. Moreover, the volunteers, who perform work identical to regular teachers, could be required to teach double-shift classes without additional compensation that would be due were they employed as regular teachers. Additionally, the collective 
rights and interests of education professionals are implicated by the program. By decree, the volunteers were prohibited from the right to freedom of association and to organize into trade unions. SUDES also complained that the government failed to consult with teachers' unions in the development of the program. The government contested this last point. Joint ILO/UNESCO Committee of Experts on the Application of the Recommendation Concerning the Status of Teachers-Report, Part 6, D, 1997.

2. The Joint ILO/UNESCO Committee of Experts (CEART), which promotes and monitors UNESCO's two recommendations on the status of teachers and of higher education teaching personnel, expressed concern in 1997 "that any extensive or permanent use of volunteers or contract teachers could undermine the status of professional teachers." Id. at Part 7. The committee also noted that volunteers who work as teachers should have the same associational rights as regular teachers. Id.

3. Following up on the matter in 2000, CEART noted the following:

The Joint Committee is most concerned with the evidence presented by both the Government and SUDES that the volunteers policy has become anchored as a permanent feature in the long-term educational development programme of Senegal. The suggestion by SUDES that all prospective teachers will henceforth pass through the voluntary programme is particularly disturbing. ... The Joint Committee... again calls on the Government's attention to paragraph 141 of the ILO/UNESCO Recommendation, 1966, which emphasizes that measures to deal with teacher shortages should be exceptional and not endanger teachers' professional standards.

Joint ILO/UNESCO Committee of Experts on the Application of the Recommendation Concerning the Status of Teachers - Report, Annex 2(2)(D) (2000). Was the initial SUDES representation before the ILO's GB premature? Should SUDES have based the representation on a different ILO convention? Senegal ratified Convention No. 87 (Freedom of Association and the Right to Organize) in 1960 and Convention No. 98 (Right to Organize and Collective Bargaining) in 1961.

4. For its part, the Senegalese government was in an exceptionally tight spot. Structural adjustment curbs on hiring public sector employees, accepted as a condition for international loans, constrain the creation of a sufficient pool of teachers to meet its goal of universal primary education. The latter, in conjunction with a lack of public financial resources, prompted the creation of the volunteers program, which sought to create a corps of low-paid paraprofessionals. Today, with some improvements in pay and the creation of a career path to contract status, and even the possibility of regular civil service employment, socalled volunteers make up a significant percentage of the primary school 
102 Chapter 2 The International Labour Organization and International Labor Standards

teaching force. Peter Coles, Wanted! Teachers, Education Today Newsletter (UNESCO), Jan.-Mar. 2005, at 4-7.

5. Senegal is not the only developing country facing a severe teacher shortage. To meet the goal of universal primary education (UPE) by 2015, more than 10.3 million teachers must be recruited worldwide. The countries in sub-Saharan Africa, including Senegal, require an additional 1.2 million teachers. Joint ILO/UNESCO Committee of Experts on the Application of the Recommendations Concerning Teaching Personnel - Report, Tenth Session (2010). For Senegal to meet the 2015 UPE goal, it must increase the present number of teachers by 5.6 percent annually. UNESCO Institute for Statistics, Information Sheet No. 5, The Global Demand for Primary Teachers (2010), at 5.

6. Many developing countries have adopted "short-term, finance-driven measures ... engaging unqualified or poorly qualified teachers on a short-term contractual basis." Joint ILO/UNESCO Committee of Experts on the Application of the Recommendations Concerning Teaching Personnel - Report, Ninth Session (2007), at viii. Moreover, CEART notes that " $\mathrm{t}]$ he recruitment of ... unqualified personnel as teachers, initially adopted as a temporary or emergency measure, has now become a more persistent and widespread practice." Id. at 12.

7. Senegal, which pioneered the concept of contract teaching through its volunteer program, now employs about 50 percent of its teachers under short-term contract. The salaries and working conditions of contract teachers are significantly below those of civil service teachers. See Alec Fyfe, The Use of Contract Teachers in Developing Countries: Trends and Impact (ILO Working Paper, 2007), at vii. The more working conditions deteriorate for professionals, the greater the impetus to migrate. Indeed, the International Organization for Migration recently noted a shift in Senegal from a destination country to one of professional emigration. International Organization for Migration, Migration au Sénégal: Profil National 2009, available at http://publications. iom.int/bookstore/index.php?main_page $=$ product_info\&cPath $=41$ _ 42\&products_id $=554$.

\section{b. Complaints Filed under Article 26}

A second adversarial mechanism involves the filing of complaints under Article 26 of the ILO Constitution. The complaint procedure is reserved for serious cases of member nation noncompliance with ratified conventions. Complaints may be filed against a member nation by another member country that is a party to the treaty at issue. The GB may also initiate the process on its own motion or after receiving a complaint from any ILC delegate. In some cases, the GB will establish a Commission of Inquiry to investigate and report on the case. In others, the case is forwarded to the Committee on Freedom of Association, which will be described below. In still other cases, the ILO has settled the matter. Swepston, International Labour Law, at 164. 
The complaint process, unlike the process administered by the CEACR, can result in a legally binding determination that a member state is in breach of its treaty obligations. Commission of Inquiry findings become binding when the member country agrees to accept them, or declines to appeal the matter to the International Court of Justice, which it is permitted to do under Article 29 of the ILO Constitution, but which no member nation has done to date. Hepple, supra, at 50.

\section{Report of the Commission of Inquiry Appointed Under Article 26 of the Constitution of the International Labour Organization to Examine the Observance by Myanmar of the Forced Labour Convention}

1930 (No. 29) Published: 1998

1. By a letter dated 20 June 1996 addressed to the Director-General of the ILO, 25 Workers' delegates to the 83rd Session of the International Labour Conference (June 1996) presented a complaint under article 26 of the Constitution against the Government of Myanmar for non-observance of the Forced Labour Convention, 1930 (No. 29), which it ratified on 4 March 1955 and which came into force for Myanmar on 4 March 1956....

\section{PART III ... SUMMARY OF THE COMPLAINT AND THE GOVERNMENT'S OBSERVATIONS}

100. In their complaint and supplementary evidence, the complainants referred to earlier findings by ILO supervisory bodies concerning noncompliance with the forced labour Convention by Myanmar. The complainants alleged that, far from acting to end the practice of forced labour, the Government of Myanmar was still engaged actively in its promotion, so that it was today an endemic abuse....

110. Before responding to the complainants' allegations, the Government described its initiatives for the emergence of a peaceful, modern and developed nation, its political, economic and social objectives, and the benefits which the local population and the nation as a whole draw from the building of infrastructures throughout the country, in particular the building of new railroads, but also motor roads, irrigation facilities, schools, hospitals, market places, parks and new towns through the collective efforts of the State, the people and the members of the Myanmar armed forces (Tatmadaw)....

[The Government asserted that all labor utilized as porters by the military, and for major public and private construction projects, was voluntary and compensated. It further noted that all relevant national laws had been reviewed and redrafted.]

120. In conclusion, the Government indicated that the Myanmar authorities were aware of the criticisms made by some Worker delegates relating to the use of labour in Myanmar for national development projects. A considerable portion of the criticisms were unfortunately based on biased and specious 
104 Chapter 2 The International Labour Organization and International Labor Standards

allegations made by expatriates living outside Myanmar who wished to denigrate the Myanmar authorities for their own ends....

\section{PART IV ... EXAMINATION OF THE CASE BY THE COMMISSION ...}

\section{B. Requirements of the Forced Labour Convention, 1930 (No. 29) ...}

205. The basic obligation undertaken by a State which ratifies the Forced Labour Convention, 1930, is "to suppress the use of forced or compulsory labour in all its forms within the shortest possible period." [Article 1(1)] This obligation to suppress the use of forced or compulsory labour, as defined in the Convention, includes for the State both an obligation to abstain and an obligation to act. In the first place, the State must neither exact forced or compulsory labour nor tolerate its exaction, and it must repeal any laws and statutory or administrative instruments that provide or allow for the exaction of forced or compulsory labour, so that any such exaction, be it by private persons or public servants, is found illegal in national law. Secondly, the State must ensure that "the illegal exaction of forced or compulsory labour shall be punishable as a penal offen $[s] \mathrm{e}$ " and "that the penalties imposed by law are really adequate and are strictly enforced." [Article 25] ...

206. The Convention defines "forced or compulsory labour" as "all work or service which is exacted from any person under the menace of any penalty and for which the said person has not offered himself voluntarily." [Article 2(1)] As noted by the Committee of Experts on the Application of Conventions and Recommendations, it was made clear during the consideration of the draft instrument by the Conference that the penalty here in question need not be in the form of penal sanctions, but might take the form also of a loss of rights or privileges....

[The Commission noted that Article 2(2) of the Convention specifically exempts from the definition of forced or compulsory labor, certain types of service including: compulsory military service of a purely military character; normal civic obligations like jury service; some types of prison labor; service required in emergencies; and minor communal service.]

... Legislation of Myanmar relevant to the case ...

237. After having stated for many years that the provisions of the Village Act (1908) and the Towns Act (1907) which empower headmen and rural policemen to impose compulsory labour on residents of the labouring class had become obsolete and were no longer applied, the Government indicated in October 1993 that "the use of voluntary labour, alleged compulsory or forced labour, is made only for the urgent necessity in accordance with the following provisions: (a) section 8(1)(g)(n) and (o) of the Village Act (1908); (b) section 9(b) of the Towns Act."

238. The relevant provisions of section 8(1) of the Village Act (1908) were submitted by the Government in October 1993 in the following wording:

Every headman shall be bound to perform the following public duties, namely:

(g) to collect and furnish, upon receipt of payment for the same at such rates as the Deputy Commissioner may fix, guides, messengers, porters, 
supplies of food, carriage and means of transport for any troops or police posted in or near or marching through the village-tract or for any servant of the Government travelling on duty: provided that no headman shall requisition for personal service any resident of such village-tract who is not of the labouring class and accustomed to do such work as may be required;

(n) generally to assist all officers of the Government in the execution of their public duties; and

(o) generally to adopt such measures and do such acts as the exigency of the village may require.

Section 7(1)(m) of the Towns Act (1907) corresponds to section 8(1)(n) of the Village Act (1908) and is also preceded by a proviso "that no headman shall requisition for personal service any resident of such ward who is not of the labouring class and accustomed to do such work as may be required."

239. Under Section 11 of the Village Act:

Every person residing in the village-tract shall be bound to perform the following public duties, namely:

$(\ldots)(d)$ on the requisition of the headman or of a rural policeman, to assist him in the execution of his duties prescribed in sections 7 and 8 of the Act and the rules made under the Act. ...

Under section 12 of the same Act:

If any person residing in a village-tract refuses or neglects to perform public duties imposed upon him by this Act or by any rule thereunder, he shall, in the absence of reasonable excuse, the burden of proving which shall lie upon him, be liable:

(i) by order of the headman, to fine ...; or

(ii) by order of the village committee, on the case being referred to it by the headman, to fine..., or to confinement for a term not exceeding 48 hours in such place as the Deputy Commissioner may appoint in this behalf, or to both; or

(iii) on conviction by a Magistrate, to fine ..., or to imprisonment for a term not exceeding one month, or to both....

[Similar provisions to those above are found in section 9 of the Towns Act (1907).]

245. ... [The Government's] concern about "causing misery and sufferings to the local population" and the non-remuneration of labour obtained "from the local populace in carrying out national development projects, such as construction of roads, bridges and railways as well as the building of dams and embankments" ... was expressed in an Order dated 2 June 1995 by the Chairman of the State Law and Order Restoration Council (SLORC) to State/Division Law and Order Restoration Councils on the subject of "Prohibiting unpaid labour contributions in national development projects." While marked "secret," this Order has according to the Government "the full legal force and effect in Administrative Law." The Order makes no reference to the Village Act or the Towns Act. It notes in paragraph 1 that "it has been learnt that in 
obtaining labour from the local populace in carrying out national development projects, such as construction of roads, bridges and railways as well as building of dams and embankments, the practice is that they have to contribute labour without compensation." While observing (in paragraph 3) that "causing misery and sufferings to the people in rural areas due to the so-called forced and unpaid labour is very much uncalled for," the Order does not put into question the requisition of labour for national development projects but stresses (in paragraph 2) that "it is imperative that in obtaining the necessary labour from the local people, they must be paid their due share." ...

258. Under section 374 of the [Myanmar] Penal Code: Whoever unlawfully compels any person to labour against the will of that person shall be punished with imprisonment of either description for a term which may extend to one year, or with fine, or with both.

... Findings of the Commission concerning the facts ...

274. Information provided to the Commission indicated that the Myanmar authorities, including the local and regional administration, the military and various militias, forced the population of Myanmar to carry out a wide range of tasks. Labour was exacted from men, women and children, some of a very young age. Workers were not paid or compensated in any way for providing their labour, other than in exceptional circumstances, and were commonly subjected to various forms of verbal and physical abuse including rape, torture and killing. The vast majority of the information covered the period since 1988, the year in which the State Law and Order Restoration Council (SLORC) came to power. While the information indicated that the use of forced labour for all the purposes discussed was prevalent since at least 1988, the use of forced labour on infrastructure-related work appeared to have been much less common before 1992....

275. The information provided indicated that Myanmar's military and various militias made systematic and widespread use of civilians to provide logistical support. This most commonly involved the use of porters to carry a range of supplies and equipment. In comparison to other forms of compulsory labour, the treatment of porters, especially during military offensives, was particularly brutal; such porters were also likely to be exposed to danger in combat situations.

276. In addition to providing porters for the military, villagers across the country, and to a lesser extent urban residents, were required to construct and repair military camps and provide general workers for these facilities on a permanent basis. A number of villagers had to be on permanent stand-by at camps to act as messengers. Villagers also had to provide the necessary materials for the construction and repair of these facilities....

277. The information also disclosed a variety of other tasks that people throughout Myanmar were requisitioned to carry out in support of the military, such as acting as guides, sentries and minesweepers. It appeared that such people were also used as human shields, in that they would be sent ahead of troops to draw enemy fire, trip booby-traps, or as hostages to prevent attacks against columns or army camps.... 
278. The question of forced recruitment into the Tatmadaw and various militia forces was also brought to the attention of the Commission. In some cases recruits appeared to be arbitrarily requisitioned, without any reference to compulsory military service legislation, and included minors....

280. The information revealed that over the last ten years the Government of Myanmar had implemented a large number of national and local infrastructure projects, in particular the construction and improvement of various roads and railways and associated infrastructure such as bridges. These projects appeared to be constructed in large part with the use of forced labour, sometimes involving hundreds of thousands of workers.

281. Similarly, it appeared that forced labour was used by the Government in relation to a range of other infrastructure projects and public works such as dams, irrigation works and airports.

282. Urban residents in particular were required to work, usually one day per week, on the cleaning and maintenance of urban areas. This was organized by the ward authorities, but was often supervised by the military....

284. It appeared that persons exacting forced labour in Myanmar were not subject to legal sanction, and were therefore enjoying full impunity. Several witnesses who had undertaken general research and investigation informed the Commission that there had been, to their knowledge, no cases of persons being punished for forcing others to provide their labour, or for committing abuses against those so forced.

285. The numbers of people in Myanmar affected by forced labour appeared to be vast. In 1995, Human Rights Watch/Asia estimated that since 1992 at least two million people had been forced to work without pay on the construction of roads, railways and bridges....

292. The information before the Commission was that the penalties for failing to comply with forced labour demands were harsh. Punishments included detention at the army camp, often in leg-stocks or in a pit in the ground, commonly accompanied by beatings and other forms of torture, as well as deprivation of food, water, medical attention and other basic rights. Women were subject to rape and other forms of sexual abuse at such times....

... National laws and statutory or administrative standard-setting instruments, considered in the light of the Convention

470. The Commission notes that section 11(d), read together with section 8(1)(g), (n) and (o) of the Village Act, as well as section 9(b) of the Towns Act provide for the exaction of work or services from any person residing in a village tract or in a town ward, that is, work or services for which the said person has not offered himself or herself voluntarily, and that failure to comply with a requisition made under section 11(d) of the Village Act or section 9(b) of the Towns Act is punishable with penal sanctions under section 12 of the Village Act or section 9A of the Towns Act. Thus, these Acts provide for the exaction of "forced or compulsory labour" within the definition of Article 2(1) of the Convention. ...

471. The Commission notes that the provisions of the Village Act and the Towns Act under which residents may be required to perform forced or compulsory labour on a general or individual requisition of the headman are 
"widely worded," as was also noted in Executive Orders made under the Village Act; indeed, residents are to assist the headman in the execution of his public duties, which in turn include the duty to supply guides, messengers, porters, etc., to any troops or police posted near or marching through a village tract and generally to assist all officers of the Government in the execution of their public duties. Thus, the labour and services that may be exacted under the Village Act and the Towns Act are as indefinite as the needs of the Government; they are limited neither to emergencies nor to minor communal services as defined in Article 2, paragraph 2(d) and (e), of the Convention, and more generally do not come under any of the exceptions listed in Article 2, paragraph 2....

473. Section $8(1)(\mathrm{g})$ of the Village Act provides for payments to headmen for the collection and supply of guides, messengers, porters, etc., but nowhere in the Village Act or Towns Act is provision made for any payment to residents called up for labour or services. The (secret) order dated 2 June 1995 on "Prohibiting unpaid labour contributions in national development projects" stresses that "in obtaining the necessary labour from the local people, they must be paid their full share." ... [T] he mere payment of wages for labour obtained through the call-up of local residents does not remove such labour from the scope of the definition of forced or compulsory labour in Article 2(1) of the Convention. Payment does not change the character of labour exacted compulsorily or by force; it merely becomes paid compulsory or forced labour....

475. More importantly, evidence before the Commission on actual practice, ... shows the continued call-up of local people for labour and services (without any compensation)....

478. Section 374 of the Penal Code ... complies with the first requirement of Article 25 of the Convention, namely that "The illegal exaction of forced or compulsory labour shall be punishable as a penal offence." Whether the penalties under section 374, which may range from a fine to imprisonment of up to one year or both, do comply with the second requirement of Article 25 of the Convention, namely that they "are really adequate," could only be appreciated if they were "strictly enforced," as Article 25 of the Convention furthermore requires. In the absence of any indication that section 374 of the Penal Code was ever applied, the Commission is bound to point out that penalties under that provision, as well as under Article 25 of the Convention, are to be imposed for the exaction of forced or compulsory labour that is found illegal. Thus, only a requisition of labour and services that is not covered by the very wide provisions of the Village Act or the Towns Act could, in theory, be punished at the present stage under section 374 of the Penal Code, while forced labour imposed in violation of the Convention but in conformity with the Village Act or the Towns Act might not be punishable at the national level....

\section{PART V ... CONCLUSIONS AND RECOMMENDATIONS ...}

536. In conclusion, the obligation under Article 1, paragraph 1, of the Convention to suppress the use of forced or compulsory labour is violated in Myanmar in national law, in particular by the Village Act and the Towns 
Act, as well as in actual practice in a widespread and systematic manner, with total disregard for the human dignity, safety and health and basic needs of the people of Myanmar.

537. Concurrently, the Government violates its obligation under Article 25 of the Convention to ensure that the penalties imposed by law for the illegal exaction of forced or compulsory labour are both really adequate and strictly enforced. While section 374 of the Penal Code provides for the punishment of those unlawfully compelling any person to labour against the will of that person, that provision does not appear to be ever applied in practice, even where the methods used for rounding up people do not follow the provisions of the Village Act or the Towns Act, which are in any event never referred to in practice...

539. In view of the Government's flagrant and persistent failure to comply with the Convention, the Commission urges the Government to take the necessary steps to ensure:

(a) that the relevant legislative texts, in particular the Village Act and the Towns Act, be brought into line with the Forced Labour Convention, 1930 (No. 29) as already requested by the Committee of Experts on the Application of Conventions and Recommendations and promised by the Government for over 30 years, and again announced in the Government's observations on the complaint. This should be done without further delay and completed at the very latest by 1 May 1999;

(b) that in actual practice, no more forced or compulsory labour be imposed by the authorities, in particular the military....

(c) that the penalties which may be imposed under section 374 of the Penal Code for the exaction of forced or compulsory labour be strictly enforced, in conformity with Article 25 of the Convention. This requires thorough investigation, prosecution and adequate punishment of those found guilty....

540. The recommendations made by the Commission require action to be taken by the Government of Myanmar without delay. The task of the Commission of Inquiry is completed by the signature of its report, but it is desirable that the International Labour Organization should be kept informed of the progress made in giving effect to the recommendations of the Commission. The Commission therefore recommends that the Government of Myanmar should indicate regularly in its reports under article 22 of the Constitution of the International Labour Organization concerning the measures taken by it to give effect to the provisions of the Forced Labour Convention, 1930 (No. 29), the action taken during the period under review to give effect to the recommendations contained in the present report....

\section{Notes}

1. The establishment of a Commission of Inquiry is a rare event reserved for cases involving the most serious, persistent violations of the ILO's 
conventions. Indeed, since 1919, the GB has appointed less than a dozen Commissions of Inquiry. Commissions, which consist of three eminent jurists or scholars, play both investigatory and adjudicatory roles. To those ends, they establish their own procedures, take testimony, request and review documentation, and, if permitted by the country in question, may make site visits to ascertain conditions first hand. Swepston, International Labour Law, at 164. The report prepared by a Commission of Inquiry is a manifestation of its adjudicatory function, stating the factual findings, legal conclusions, and recommendations in the case. The member country in question is given three months to either accept the report or indicate that it will appeal to the International Court of Justice, the latter which, as noted above, is a step that has never been taken by any country. Potter, The ILO, at 85-23.

2. A country that refuses to carry out the recommendations of a Commission of Inquiry is subject to Article 33 of the ILO Constitution, which provides:

In the event of any Member failing to carry out within the time specified the recommendations, if any, contained in the report of the Commission of Inquiry, or in the decision of the International Court of Justice, as the case may be, the Governing Body may recommend to the [International Labor] Conference such action as it may deem wise and expedient to secure compliance therewith.

ILO Constitution, Article 33. This constitutional provision lay dormant until the Myanmar case.

3. In June 1999, almost one year after the Commission of Inquiry in the Myanmar case issued its recommendations, the ILC passed a resolution that condemned the state's refusal to institute the Commission's recommendations; prohibited any ILO technical assistance other than that necessary to implement the recommendations; and banned Myanmar from attending most ILO meetings. Potter, The ILO, at 8524. The following year, in June 2000, the ILC adopted a resolution proposed by the GB invoking Article 33. Among other things, the resolution asked ILO members and international organizations to review and take appropriate measures regarding their relationships with Myanmar to avoid abetting the practice of forced labor. Hepple, supra, at 51. Encompassed within such a re-examination was the possibility that trade sanctions might be imposed upon Myanmar by the member states. Potter, The ILO, at 85-25.

4. Since then, the Myanmar government has agreed to the appointment of an ILO liaison officer in Myanmar, and allowed an ILO very High Level Team to travel to the country to assess the progress being made to eliminate the use of forced labor. A 2005 CCAS report on Myanmar, however, noted that the extent of the use of forced labor in most areas of Myanmar had not been significantly reduced. Moreover, neither the Village Act nor the Towns Act, which authorize the use of forced labor, 
had been repealed. The ILO liaison officer had not been permitted to travel freely throughout the country, and the very High Level Team was not met by high-level government officials, and cut short its mission. The CCAS noted that it was particularly alarmed at the government's stated intention to prosecute those accused of falsely lodging complaints of forced labor, and also at the apparent intimidation of complainants seeking contact with the ILO liaison officer. Conference Committee on the Application of Standards, Special Sitting to Examine Developments Concerning the Question of the Observance by the Government of Myanmar of the Forced Labour Convention, 1930 (No. 29) (2005).

5. In June 2008, as it has every year since 2001, the ILO's Conference Committee on the Application of Standards held a special sitting concerning Myanmar's application of Convention No. 29. Two significant series of events - one political and the other natural formed the backdrop for the discussion. The first involved the significant public demonstrations against the government in September 2007, which were prompted by the government's increase of fuel prices. These mass demonstrations, led at first by dissidents and then mainly by Buddhist monks, were ruthlessly suppressed by the government. Seth Mydans, Myanmar Monks Protests Contained by Junta's Forces, N.Y. Times, Sept. 28, 2007, at A1.

6. As for the natural occurrence, in May 2008, shortly before the International Labour Conference, Myanmar was hit by Cyclone Nargis, which devastated the country's Irrawaddy and Yangon Divisions. An estimated 130,000 people died as a result of the storm. A slow response by the government, and its initial unwillingness to let foreign aid workers enter affected areas, compounded the tragedy. Burmese Endure in Spite of Junta, Aid Workers Say, N.Y. Times, June 18, 2008.

7. Discussion at the June 2008 special sitting highlighted an interesting development: The Myanmar government, represented at the sitting, reported that a new State Constitution had been approved by national referendum in May 2008. Apparently over 26.8 million people voted in favor of adopting the Constitution, representing 92.48 percent of the vote. The Constitution contains a provision relating to forced labor, stated the government representative. See Conference Committee on the Application of Standards: Extracts from the Record of Proceedings, Part III, Ninety-Seventh Session, Geneva, 2008, Convention 29, Forced Labour Convention, 1930 Myanmar (ratification: 1955), at 3 (hereinafter Conference Committee Special Sitting).

8. Worker members at the 2008 special sitting noted that the new Constitution's prohibition of forced labor was unclear and contained so many caveats and restrictions that it contradicts Convention No. 29. See id. at 4 . Nevertheless, there is evidence of very slow progress in amending legislation at odds with Convention No. 29. At its March 2011 session, the ILO Governing Body "note[d] the [Myanmar] Government's indication that draft legislation aimed at achieving 
legislative conformity with Convention No. 29 is in the process of preparation." The GB invited the Government of Myanmar to avail itself of ILO technical assistance "with a view to the rapid amendment of the Village and Towns Acts...." Governing Body, Decision on the Fifth Item on the Agenda: Developments Concerning the Question of the Observance by the Government of Myanmar of the Forced Labour Convention, 1930 (No. 29), Mar. 24, 2011 (hereinafter, Governing Body, Decision on the Fifth Item (Forced Labour)).

9. A February 2007 Supplementary Understanding between the ILO and the Myanmar government established a complaint mechanism for forced labor victims that allows them to lodge complaints directly with the ILO liaison officer, who then communicates with the government's Working Group. The Myanmar government representative at the June 2008 special sitting reported progress on the implementation of the Supplementary Understanding. A translation of the Supplementary Understanding into the Myanmar language was completed and posted on the Ministry of Labor's website, noted the government representative. Additionally, the government had taken steps to publicize the Supplementary Understanding through a March 2007 press conference. See Conference Committee Special Sitting at 3. In March 2011, the Governing Body welcomed the extension of the Supplementary Understanding for another year, and noted an increase in the number of cases filed under it. Governing Body, Decision on the Fifth Item (Forced Labour).

10. The Myanmar government's ruthless suppression of freedom of association has long been an ILO concern. The new Constitution, however, contains specific articles on freedom of association, freedom of expression, and the right to organize. An English translation of the Constitution is available at http://www.scribd.com/doc/7694880/MyanmarConstitution-2008-English-version. Chapter VII, Section 354 provides in pertinent part:

Every citizen shall be at liberty in the exercise of the following rights, if not contrary to the laws, enacted for Union security, prevalence of law and order, community peace and tranquility or public order and morality:

(a) to express and publish freely their convictions and opinions;

(b) to assemble peacefully without arms and holding procession;

(c) to form associations and organizations....

Constitution of the Republic of the Union of Myanmar, 2008, Chapter VII, Section 354. The right to organize trade unions is not expressly provided for.

11. At the June 2010 International Labour Conference, several worker delegates filed an Article 26 complaint against Myanmar for violation of Convention No. 87 (Freedom of Association). At its March 2011 meeting, the Governing Body, having examined the Myanmar 
government's response to the complaint, deferred its decision on appointing a Commission of Inquiry until its November 2011 session. The GB also requested the Myanmar government produce for review that government's supposed "draft law on Labour Organizations." Governing Body, Decision on the Sixth Item on the Agenda: Complaint Concerning the Observance by Myanmar of the Freedom of Association and Protection of the Right to Organise Convention, 1948 (No. 87), Made by Delegates to the 99th Session (June 2010) of the International Labour Conference Under Article 26 of the Constitution of the ILO, Mar. 24, 2011.

12. As noted above, the Myanmar government's treatment of freedom of association is infamous. Illustrative of its methods was a general election, aimed at the supposed continued democratization of the country, which was held November 7, 2010, while opposition leader and Nobel Peace Prize winner Aung San Suu Kyi was still under house arrest. She was released on November 13, 2010. In March 2011, the GB called for the release from detention of a number of specific individuals, including labor activists and "persons associated with the making of, or supporting the submission of, complaints under the Supplementary Understanding." Governing Body, Decision on the Fifth Item (Forced Labour). Notably, in October 2011, Myanmar released an estimated 120 political prisoners, "a small fraction of the 2,000 or so ... that Amnesty International estimates to be behind bars." Seth Mydans, Myanmar Begins to Release Some of Its Political Prisoners, N.Y. TIMES, Oct. 12, 2011. Many commentators see the prisoners' release, and other recent steps, as evidence of systemic change by one of the world's most closed and inflexible governments. Id.

13. The ILO's procedures for enforcing international labor standards are directed at member states rather than at private employers. Yet private employers may directly or indirectly bear responsibility for abysmal working conditions. In the Myanmar case, for example, there was evidence in the form of secondary statements that forced labor was used for helipad construction and ground clearance work for the Yadana gas pipeline project, a joint venture of French oil company Total, American-owned oil giant Unocal, and the Myanmar Oil and Gas Enterprise, a state-owned company established by the Myanmar military. The Commission of Inquiry, which had requested and been denied access to the country by the Myanmar government, could make no finding on the matter. Report of the Commission of Inquiry Appointed Under Article 26 of the Constitution of the International Labour Organization to Examine the Observance by Myanmar of the Forced Labour Convention, 1930 (No. 29), at 452.

14. Human rights activists found another device for addressing the alleged atrocities committed in connection with the Yadana gas pipeline project. In the fall of 1996, two suits were filed in U.S. federal court by Myanmar villagers who suffered abuses at the hands of the Myanmar military related to the project. The suits were brought against 
Myanmar, Total, and Unocal, and based largely on the U.S. Alien Tort Claims Act (ATCA), 28 U.S.C. $\$ 1350$, a controversial 200-year-old statute that lay dormant until 1980. The ATCA confers upon the U.S. federal district courts "original jurisdiction of any civil action by an alien for a tort only, committed in violation of the law of nations." Id. Ultimately, the claims against the Myanmar military and Myanmar Oil were dismissed because those entities were entitled to sovereign immunity. The claims against Total were dismissed for lack of personal jurisdiction. Doe I v. Unocal Corp., 395 F.3d 932, 943 (9th Cir. 2002). The case against Unocal, however, wound its way through federal and California state court, and was ultimately settled in March 2005. Although the settlement amount is confidential, the parties announced that the money will be used to compensate and protect the villagers, and develop programs in the pipeline region to improve health care, living conditions, and education. Marc Lifsher, Unocal Settles Human Rights Lawsuit over Alleged Abuses at Myanmar Pipeline, L.A. Times, Mar. 22, 2005. Chapter 14 includes an excerpt of the Unocal case and discusses in greater detail use of the Alien Tort Claims Act as a mechanism for enforcing international labor rights in U.S. courts.

\section{c. The Committee on Freedom of Association}

A special body was created by the ILO in 1950 to examine complaints brought by governments, workers' organizations, or employers' organizations that an ILO member nation's law or practice violates principles of freedom of association (CFA). The CFA is a tripartite body composed of nine members of the GB, and presided over by an independent chair. It draws its authority from the ILO Constitution, along with the Declaration of Philadelphia, both of which embody, inter alia, freedom of association as a fundamental principle that all ILO members agree to observe. Thus, ratification of the freedom of association conventions, Conventions Nos. 87 and 98, is not a prerequisite to bringing a complaint against a member country before the CFA. Swepston, International Labour Law, at 165.

The CFA generally decides cases on the basis of documentary evidence. It usually reaches decisions by consensus. HePpLE, supra, at 52. The CFA meets three times annually, and has reviewed over 3,000 cases. Potter, The ILO, at 85-28.

\section{Committee on Freedom of Association, Complaint Against the Government of Canada Concerning the Province of Ontario Presented by the Ontario Federation of Labour (OFL) and the Canada Labour Congress (CLC)}

Case No. 2182, Report No. 330 (2003)

\section{INTRODUCTION}

Allegations: The complainants allege that some provisions of the Ontario Labour Relations Act encourage the decertification of workers' organizations by requiring employers to post and distribute in the workplace documents setting out the process to terminate trade union bargaining rights.... 
308. Canada has ratified the Freedom of Association and Protection of the Right to Organise Convention, 1948 (No. 87). It has not ratified the Right to Organise and Collective Bargaining Convention, 1949 (No. 98), the Labour Relations (Public Service) Convention, 1978 (No. 151), nor the Collective Bargaining Convention, 1981 (No. 154).

\section{BACKGROUND}

\section{A. The Complainants' Allegations}

309. The Ontario Federation of Labour (OFL), affiliated to the Canadian Labour Congress, is made up of 650,000 workers in more than 1,500 affiliated local unions. This complaint concerns some provisions of the Labour Relations Amendment Act, 2000 (Bill No. 139) which, according to the OFL, infringe guarantees of freedom of association and, in particular, ILO Conventions Nos. 87, 98 and 151. These provisions encourage the decertification of workers' organizations by requiring employers to post and distribute in the workplace documents prepared by the Minister of Labour, setting out the process to terminate trade union bargaining rights.

310. Bill No. 139 passed third reading and received royal assent in December 2000. These provisions are now contained in section 63.1 of the Labour Relations Act (the LRA), which provides:

63.1(1) Within one year after the day the Labour Relations Amendment Act, 2000, receives royal assent, the Minister shall cause to be prepared and published a document describing the process for making an application for a declaration that the trade union no longer represents the employees in a bargaining unit....

63.1(3) The document shall explain who may make an application, when an application may be made and the procedure, as set out in this Act and in any rules made by the chair of the Board ... that the Board follows in dealing with an application.

63.1(4) An employer with respect to whom a trade union has been certified as a bargaining agent ... shall use reasonable efforts:

(a) to post and keep posted a copy of a document published under this section in a conspicuous place in every workplace of the employer at which employees represented by the trade union perform work;

(b) to post and keep posted with that copy a notice that any employee represented by the trade union may request a copy of the document from the employer;

(c) once in each calendar year, to provide a copy of the document to all employees of the employer who are represented by the trade union; and

(d) upon the request of an employee ... to provide a copy of the document to him or her, even though the employer has previously provided or will subsequently provide the employee with a copy of the document.

63.1(5) An employer shall not be found to be in violation of this Act as a result of doing anything set out in subsection (4). 
311. In accordance with these provisions, the Minister of Labour prepared and published a document describing the process for decertification in December 2001. A copy of the poster and brochure were mailed that same month to all employers who had registered a collective bargaining relationship with the Ministry of Labour.

312. The complainants allege that section 63.1 of the LRA contravenes Convention No. 87, ratified by Canada, and is entirely inconsistent with the Government's obligations under international law to encourage, promote and protect the right of employees to bargain collectively. This provision constitutes a powerful message by the State of its opposition to the unionization of employees and a clear interference with that right. By virtue of freedom of association principles, all workers have the right to establish and join organizations of their own choosing; governments must take measures to encourage and promote the full development and utilization of machinery for voluntary negotiation between unions and employers, and must allow trade unions to operate in full freedom.

313. The complainants submit that this provision constitutes a significant interference with the rights of employees to join and participate in the activities of trade unions. Rather than meeting its obligations at international law to encourage the process of collective bargaining, the Government of Ontario clearly intends to weaken trade unions and to encourage individuals not to exercise their right to organize or to engage in collective bargaining. Rather than encouraging the exercise of the right to collective bargaining the Government has chosen in a discriminatory and one-sided manner to promote the decertification of existing trade unions by conducting a campaign which can only be seen as designed to encourage interference with the exercise of trade union freedoms....

315. The legislation in question is noteworthy in that it advises employees only of their rights to decertify under the Labour Relations Act. It does not mention any of the rights that are intended to protect freedom of association including the right to engage in certification and in lawful activities of trade unions and to be free from discrimination or anti-union reprisal, all matters which are covered by the LRA....

316. In addition, the Government has not chosen to require that similar posters or brochures be distributed in non-union workplaces advising employees of their rights to unionize, thus making it plain that the intention of the legislative provisions is not to inform employees about relevant labour relations laws in an even-handed fashion but is rather to interfere with the right of employees who have chosen to unionize....

\section{B. The Government's Reply}

318. In its communication of 3 October 2002, the Government of Ontario submits that the obligation made to employers in unionized workplaces to post a decertification information poster under Bill No. 139 does not violate ILO Conventions Nos. 87, 98, 151 and 154. 
319. The Labour Relations Amendment Act, 2000 (Bill No. 139), which received royal assent on 21 December 2000, among other things, amended the Labour Relations Act, 1995 (LRA) to require within one year the publication of a document describing the process for making an application for a declaration that a trade union no longer represents the employees in a bargaining unit. ...

320. The document sets out neutral factual information about union decertification. It explains who may make an application, when an application may be made and the procedure as set out in the Act and in the rules of the Ontario Labour Relations Board (OLRB). Every unionized employer is required to use reasonable efforts to post a copy of the document in the workplace, provide a copy of the document to every unionized employee once per calendar year and provide a copy to unionized employees who request it. Compliance with these reasonable efforts requirements by an employer will not constitute an unfair labour practice under the Act.

321. Generally, the statutory reasonable efforts to post and distribute apply to employers with a collective bargaining relationship governed by the LRA. These requirements do not apply to employers who have no unionized employees or employers whose unionized employees are governed under other statutes, for example, firefighters covered by the Fire Protection and Prevention Act, 1997; police and related employees covered by the Police Services Act or the Public Service Act; employees of a college covered by the Colleges Collective Bargaining Act; or teachers covered by the Education Act and the Provincial Schools Negotiations Act....

323. The Government of Ontario submits that these provisions support workplace democracy and the individual right of workers freely to decide whether they wish to be represented by a union and continue with union representation. Certification information is made available to employees by unions during an organization drive but, until now, there had been little information available to employees about decertification. Unions did not provide it and employers were generally prohibited from doing so. The purpose of the decertification poster is simply to inform employees of their rights under the LRA, which they may otherwise not be aware of, by providing neutral, factual information....

\section{CONCLUSIONS}

\section{The Committee's Conclusions}

328. The Committee notes that this case concerns section 63.1 of the Labour Relations Act of Ontario (the "LRA") which provides that employers in unionized settings must post and circulate information, prepared by the Ministry of Labour, on rules and procedures for trade union decertification. ...

329. The Committee recalls that measures should be taken to guarantee freedom of association, which includes the effective recognition of collective bargaining. This necessarily implies the taking of positive steps, conducive to achieving freedom of association and the collective regulation of employment terms and conditions. 
118 Chapter 2 The International Labour Organization and International Labor Standards

330. The Committee considers that the provisions challenged in the present case cannot promote and encourage freedom of association. Quite the contrary, the poster and accompanying notice, being information prepared by the Ministry of Labour and posted in unionized workplaces with the Ministry's formal endorsement may be considered, at best, as a message by the Government that a decertification application would be entertained favourably and, at worst, as an incitement to apply for decertification, thus contravening Convention No. 87 ratified by Canada.

331. The Government's argument that the object of this provision is to provide neutral and factual information might have been more convincing had the amending legislation introduced parallel provisions, with the official endorsement of the Labour Ministry, to inform workers in all non-unionized workplaces ... of their right to organize and the procedures to do so, and of the various existing legal guarantees to ensure the free exercise of that right, e.g. protection against trade union discrimination (before and during certification), protection against employer interference, etc. ...

333. The Committee considers that section 63.1 of the LRA does not encourage the promotion of freedom of association, is not conducive to harmonious labour relations and may rather ultimately prove counterproductive by creating a recurring climate of confrontation over certification issues. The Committee considers that it would be actually advantageous for the Government to avoid this type of provision and therefore requests it to repeal section 63.1 of the LRA and to keep it informed of developments in this respect.

\section{RECOMMENDATIONS}

\section{The Committee's Recommendation}

334. In the light of its foregoing conclusions, the Committee invites the Governing Body to approve the following recommendation:

The Committee requests the Government of Ontario to repeal section 63.1 of the Labour Relations Act and to keep it informed of developments in this respect.

\section{Notes}

1. What message do the posters required under the Ontario Labour Relations Act send to unionized employees? What was the provincial government trying to achieve by requiring decertification information to be posted in unionized workplaces? Why do you think the CFA complaint was brought in this case? As noted in Chapter 4, Canada has the dubious distinction of leading the G-7 countries in the number of freedom of association complaints filed against it. Between 1954 and 2005, 91 complaints on that subject were filed against Canada with the ILO. See Chapter 4, section A (Introduction). 
2. The government in its reply stated that it was intent upon safeguarding the individual worker's right to choose to be part of a union or not. This emphasis on individual choice rather than collective workplace voice is not unique to Canadian law. Indeed, it can be found in aspects of British, American, Australian, and New Zealander law as well. Focusing on U.S. labor policy, Professor Roy Adams argues that in order to meet international human rights standards, a nation's laws must do more than guarantee an employee's choice to engage in collective bargaining. Rather, "states must ensure that all employees have in place an independent collective voice through which their employment interests may be represented." Roy J. Adams, Choice or Voice? Rethinking American Labor Policy in Light of the International Human Rights Consensus, 5 Emp. RTs. \& EMP. POL’y J. 521, 522 (2001). Similarly, Lord Wedderburn took to task British labor law for an "obsession with individualism," evidenced by the dominance of individual employment contracts over collective bargaining agreements. Lord Wedderburn, Common Law, Labour Law, Global Law, in Social ANd Labour Rights In a Global Context 19, 35-37 (Bob Hepple ed., 2002). For information on the Australian and New Zealander approaches, see Sean Cooney, A Broader Role for the Commonwealth in Eradicating Foreign Sweatshops?, 28 Melb. U. L. Rev. 290, 339 (2004); Ellen J. Dannin, Consummating Market-Based Labor Law Reform in New Zealand: Context and Reconfiguration, 14 B.U. INT'L L.J. 267 (1996).

3. The CFA notes that it is incumbent upon the government to "tak $[\mathrm{e}]$... positive steps, conducive to achieving freedom of association and the collective regulation of employment terms and conditions." Committee on Freedom of Association, Complaint Against the Government of Canada Concerning the Province of Ontario Presented by the Ontario Federation of Labour (OFL) and the Canada Labour Congress (CLC), Case No. 2182, Report No. 330, at 9 329. Does this imply that public policy must favor unionization? Article 2 of Convention No. 87 states that " $[\mathrm{w}]$ orkers ... shall have the right to establish and ... join organisations of their own choosing. ..." Article 8(2) provides that "[t] he law of the land shall not be such as to impair, nor shall it be so applied as to impair, the guarantees provided for in this Convention." Article 11 constitutes a pledge by ratifying members "to take all necessary and appropriate measures to ensure that workers ... may exercise freely their right to organise." Can these three provisions be read as imposing an affirmative duty to promote collective bargaining?

4. Bill 144, An Act to Amend Certain Statutes Relating to Labor Relations, received royal assent and came into force in Ontario, Canada on June 13, 2005. Sections 4 and 5 of the bill repeal subsections 63 and 63.1 of the Ontario Labour Relations Act, which formerly required the preparation and posting in unionized workplaces of documents on the procedures for obtaining union decertification. Bill 144, 1st Session, 38th Legislature, Ontario, 54 Elizabeth II, 2005. Does the Ontario Legislature's 
120 Chapter 2 The International Labour Organization and International Labor Standards

repeal of a provision found by the CFA to contravene Convention No. 87 constitute evidence that the ILO machinery was effective in this case? Bill 144 was introduced by Ontario's reigning Liberal Party, which came to power in 2003 promising to restore fairness and balance to labor relations, a balance it maintained had been upset by the actions of the pro-labor New Democratic Party and pro-business Progressive Conservative Party during the 1990s. Murray Campbell, A New Minister, a Dysfunctional Work Force, The Globe And Mail, Mar. 4, 2004, at A11.

5. On January 30, 2009, President Barack Obama signed Executive Order 13496, which requires most federal departments and agencies "to include within their Government contracts specific provisions requiring contractors and subcontractors...to post notices informing their employees of their rights as employees under Federal labor laws," including the National Labor Relations Act (NLRA), which protects worker freedom of association and self-organization. See Notification of Employee Rights Under Federal Labor Laws, 75 Fed. Reg. 28,368 (May 20, 2010) (to be codified at 29 C.F.R. pt. 471). The National Labor Relations Board subsequently proposed a rule requiring all employers subject to the agency's jurisdiction to post notices using the language adopted by the Department of Labor pursuant to the executive order. The executive order only affects federal government contractors and subcontractors, making the Board's proposal a significant extension of notice requirements. Lawrence E. Dubé, NLRB Proposed Rule Requires Notice Posting by All Employers Under Board's Jurisdiction, Daily Lab. Rep. (BNA), at AA-1 (Dec. 21, 2010). The Board received close to 6,500 public comments on the proposed rule by the close of the 60-day comment period, including those from business interests who consider the agency to be biased in favor of unions. Lawrence E. Dubé, NLRB Notice Proposal Draws Heavy Comment, Daily Lab. Rep. (BNA), at AA-1 (Feb. 24, 2011). Despite business opposition, the Board issued a final notice posting rule in August 2011, which is effective as of January 31,2012 . The new notice required by non-federal contractors is similar to the one required by the executive order. Will notifying employees of their right to associate and organize affect organizing rates or union density?

6. The required poster that government contractors and subcontractors must display informs employees that they have the right to organize a union for the purpose of negotiation; form, join, or assist a union; bargain collectively; discuss workplace terms and conditions of employment with their co-workers; take action with one or more co-workers to improve working conditions; strike and picket, depending on the purpose; or refrain from these activities. It also lists illegal employer and union actions. Does the poster promote collective bargaining and unionization, as its critics charge? The poster can be accessed at http://www.dol.gov/ olms/regs/compliance/EmployeeRightsPoster11x17_Final.pdf. 